\title{
Experimental Investigation of Single Carbon Compounds under Hydrothermal Conditions
}

\author{
Jeffrey S. Seewald $^{* a}$, Mikhail Yu. Zolotov ${ }^{\mathrm{b}}$, and Thomas McCollom ${ }^{\mathrm{c}}$
}

\footnotetext{
${ }^{a}$ Department of Marine Chemistry and Geochemistry, Woods Hole Oceanographic Institution, MS \#4, Woods Hole, MA 02543, jseewald@whoi.edu

${ }^{b}$ Department of Geological Sciences, Arizona State University, Tempe, Arizona 85287-1404

${ }^{c}$ Center for Astrobiology and Laboratory for Atmospheric and Space Physics, University of Colorado, Boulder CO 80309
}

\footnotetext{
* Author to whom correspondence should be addressed
} 


\begin{abstract}
The speciation of carbon in subseafloor hydrothermal systems has direct implications for the maintenance of life in present day vent ecosystems and possibly the origin of life on early Earth. Carbon monoxide is of particular interest because it represents a key reactant during the abiotic synthesis of reduced carbon compounds via Fischer-Tropsch-type processes. Laboratory experiments were conducted to constrain reactions that regulate the speciation of aqueous single carbon species under hydrothermal conditions and determine kinetic parameters for the oxidation of $\mathrm{CO}$ according to the water water-gas shift reaction $\left(\mathrm{CO}_{2}+\mathrm{H}_{2}=\mathrm{CO}+\mathrm{H}_{2} \mathrm{O}\right)$. Aqueous fluids containing added $\mathrm{CO}_{2}, \mathrm{CO}, \mathrm{HCOOH}, \mathrm{NaHCO}_{3}, \mathrm{NaHCOO}$, and $\mathrm{H}_{2}$ were heated at 150, 200, and $300^{\circ} \mathrm{C}$ and 350 bar in flexible cell hydrothermal apparatus, and the abundance of carbon compounds were monitored as a function of time. Variations in fluid chemistry suggest that the reduction of $\mathrm{CO}_{2}$ to $\mathrm{CH}_{3} \mathrm{OH}$ under aqueous conditions occurs via a stepwise process that involves the formation of $\mathrm{HCOOH}, \mathrm{CO}$, and possibly $\mathrm{CH}_{2} \mathrm{O}$, as reaction intermediaries. Kinetic barriers that inhibit the reduction of $\mathrm{CH}_{3} \mathrm{OH}$ to $\mathrm{CH}_{4}$ allow the accumulation of reaction intermediaries in solution at high concentrations regulated by metastable equilibrium. Reaction of $\mathrm{CO}_{2}$ to form $\mathrm{CO}$ involves a two-step process in which $\mathrm{CO}_{2}$ initially undergoes a reduction step to $\mathrm{HCOOH}$ which subsequently dehydrates to form $\mathrm{CO}$. Both reactions proceed readily in either direction. A preexponential factor of $1.35 \times 10^{6} \mathrm{~s}^{-1}$ and an activation energy of $102 \mathrm{KJ} \mathrm{mol}^{-1}$ were retrieved from the experimental results for the oxidation of $\mathrm{CO}$ to $\mathrm{CO}_{2}$.

Reactions rates amongst single carbon compounds during the experiments suggests $\Sigma \mathrm{CO}_{2}$ $\left(\mathrm{CO}_{2}+\mathrm{HCO}_{3}{ }^{-}+\mathrm{CO}_{3}{ }^{-}\right), \mathrm{CO}, \Sigma \mathrm{HCOOH}\left(\mathrm{HCOOH}+\mathrm{HCOO}^{-}\right)$, and $\mathrm{CH}_{3} \mathrm{OH}$ may reach states of redox-dependent metastable thermodynamic equilibrium in subseafloor and other hydrothermal systems. The abundance of $\mathrm{CO}$ under equilibrium conditions, which in turn may influence the likelihood for abiotic synthesis via Fischer-Tropsch-type processes, is strongly dependent on temperature, the total carbon content of the fluid, and host-rock lithology. If crustal residence times following the mixing of high-temperature hydrothermal fluids with cool seawater are sufficiently long, reequilibration of aqueous carbon can result in the generation of additional reduced carbon species such as $\mathrm{HCOOH}$ and $\mathrm{CH}_{3} \mathrm{OH}$ and the consumption of $\mathrm{H}_{2}$. The present study suggests that abiotic reactions involving aqueous carbon compounds in hydrothermal systems are sufficiently rapid to influence metabolic pathways utilized by organisms that inhabit vent environments.
\end{abstract}




\section{INTRODUCTION}

In recent years, abiotic chemical reactions have been discussed as a potential mechanism for the formation of reduced carbon compounds in seafloor hydrothermal systems, where $\mathrm{CO}_{2}$, $\mathrm{CO}, \mathrm{CH}_{4}$, and $\mathrm{C}_{2+}$ hydrocarbons are present as major and trace components. Because the substantial fluid flux through deep-sea hot-springs represents a potentially significant source of carbon and energy to support microbial activities in surface and sub-surface habitats, the possibility that abiotic processes may influence the speciation of carbon in vent fluids has direct implications for the maintenance of life in present day hydrothermal environments. Furthermore, models developed to account for the origin of life within a hydrothermal setting on the early Earth typically invoke abiotic chemical processes as being responsible for the production of precursor organic compounds from which life formed and evolved. Despite the significant role that aqueous carbon compounds play in a broad spectrum of geochemical and biological processes, reactions that regulate the abundance of aqueous carbon compounds at elevated temperatures and pressures are poorly constrained.

Abiotic synthesis of organic compounds in hydrothermal environments is commonly attributed to Fischer-Tropsch-type processes that involve the reduction of $\mathrm{CO}_{2}$ and/or $\mathrm{CO}$ by $\mathrm{H}_{2}$ on a catalytic surface to form bound methylene groups that polymerize into long chain hydrocarbons (Andersen, 1984). Although the process can proceed with $\mathrm{CO}_{2}$ and $\mathrm{H}_{2}$ as initial reactants, rates and yields are substantially enhanced by the presence of CO. It is generally believed that formation of hydrocarbons from $\mathrm{CO}_{2}$ involves its initial reduction to form $\mathrm{CO}$ by the water-gas shift reaction as follows:

$$
\mathrm{CO}_{2}+\mathrm{H}_{2}=\mathrm{CO}+\mathrm{H}_{2} \mathrm{O}
$$

Because this reaction allows $\mathrm{CO}_{2}$ to be used as feedstock for hydrocarbon formation by FischerTropsch synthesis, it has been the focus of much attention in the engineering literature. The overall process represented by reaction (1) is a two step process involving the formation of a formic acid intermediary that subsequently decomposes to $\mathrm{CO}$ according to the reaction:

$$
\mathrm{CO}_{2}+\mathrm{H}_{2}=\mathrm{HCOOH}
$$




$$
\mathrm{HCOOH}=\mathrm{CO}+\mathrm{H}_{2} \mathrm{O}
$$

(Elliot et al., 1983; Melius et al., 1990; Rice et al., 1998). At temperatures below $\sim 800^{\circ} \mathrm{C}$, the water-gas shift reaction is exceedingly slow when occurring in a gas phase at low water fugacities and does not occur on a laboratory time scale unless a catalyst is present (Nafziger et al., 1971; Deines et al., 1974; Ulmer, 1984; Huebner, 1987; Burkhard and Ulmer, 1995). The rates increase substantially at higher water fugacities under supercritical conditions (Rice et al., 1998). At sub- and near critical temperatures typical for seafloor hydrothermal systems, the rates of reaction (1) are poorly known.

In addition to the water-gas shift reaction, there are many other processes that may influence the speciation of carbon under hydrothermal conditions. Reactions between single carbon compounds in the C-H-O system are limited to formation of $\mathrm{CO}_{2}, \mathrm{CO}$, formic acid ( $\mathrm{HCOOH})$, formaldehyde $\left(\mathrm{CH}_{2} \mathrm{O}\right)$, methanol $\left(\mathrm{CH}_{3} \mathrm{OH}\right)$, and $\mathrm{CH}_{4}$ which can be generalized by the sequence in Figure 1. If formation of carbon-carbon bonds is considered, an almost limitless number of reactions are possible that may influence carbon speciation. It is important to recognize that although Fischer-Tropsch-type processes may produce $\mathrm{CH}_{4}$ and longer chain hydrocarbons from $\mathrm{CO}_{2}$, it should not be viewed as the only mechanism available to produce reduced carbon species at elevated temperatures and pressure. In particular, production of $\mathrm{CH}_{4}$ may occur in aqueous solution without the involvement of a heterogeneous catalyst or gas phase. This study was conducted to investigate aqueous processes that influence the speciation of single carbon compounds under conditions typical of seafloor hydrothermal systems and builds on previous work that shows formic acid and $\mathrm{CO}_{2}$ equilibrate rapidly at the prevailing redox conditions in many low-temperature hydrothermal environments (McCollom and Seewald, 2003). In particular, an experiment was designed to constrain the rates of reactions that regulate the abundance of $\mathrm{CO}$ as a function of $\mathrm{pH}$, redox conditions, and temperature in the absence of an added catalyst. The results have direct applications to models that account for abiotic synthesis and the speciation of carbon in hydrothermal systems on Earth and other solar system bodies.

\section{METHODS}


Flexible-cell hydrothermal apparatus (Seyfried et al., 1987) was used for the experiment. This equipment consists of a flexible gold reaction cell with a titanium closure piece and exit tube that is encased in a stainless steel pressure vessel. External control of pressure within the steel vessel allows elimination of a vapor head-space within the flexible reaction cell. A stainless steel valve attached to the exit tube allows removal of fluid from the reaction cell for chemical analysis without disturbing the temperature and pressure conditions of an experiment. The composition of reactants within the reaction cell can be modified by injecting fluids through the sampling valve using a high pressure pump. The experiment was conducted at 150, 200, and $300^{\circ} \mathrm{C}$ and 350 bar. Prior to the experiment, titanium components of the reaction cell were heated at $400^{\circ} \mathrm{C}$ in air to form a chemically inert $\mathrm{TiO}_{2}$ surface layer. Because the goal of this investigation was to examine the uncatalyzed rates of aqueous reactions involving single carbon compounds, heterogeneous catalysts were not added during any phase of the experiment. Although the possibility exists that some of the reactions being studied may be catalyzed by the gold-titanium reaction cell, previous studies have not revealed catalytic properties for $\mathrm{Au}$ and $\mathrm{TiO}_{2}$ with respect to carbon chemistry under hydrothermal conditions (Bell and Palmer, 1994; Bell et al., 1994; McCollom and Seewald, 2001, 2003).

The general approach used to examine equilibration of $\mathrm{CO}$ and $\mathrm{CO}_{2}$ during this study involved creating thermodynamic disequilibrium within the chemical system and subsequently monitoring changes in fluid chemistry as a function of time. At chemical equilibrium according to reaction (1), fluid composition is constrained by the mass action expression:

$$
K_{e q}=\frac{a_{\mathrm{CO}} a_{\mathrm{H} 2 \mathrm{O}}}{a_{\mathrm{CO} 2} a_{\mathrm{H} 2}}
$$

where $K_{e q}$ is the equilibrium constant and $a_{j}$ is the activity of aqueous species $j$. Chemical disequilibrium was induced by a variety of methods including addition of $\mathrm{CO}_{2}, \mathrm{H}_{2}$, or $\mathrm{CO}$, varying $\mathrm{pH}$, and dilution of reaction cell contents with deionized water (Table 1). In the latter case, equal magnitude reductions in the aqueous concentrations of all dissolved gases in the reaction cell by dilution induces disequilibria because the denominator in equation 4 is affected to a greater extent than the numerator. Varying temperature was less effective as a means to 
induce disequilibria during this study because the equilibrium constant for reaction 1 does not change substantially in the temperature range of 150 to $300^{\circ} \mathrm{C}$ (Fig. 2).

Owing to technical difficulties associated with injecting large amounts of gaseous reactants into the reaction cell, addition of initial excess $\mathrm{CO}_{2}$ and $\mathrm{H}_{2}$ was achieved by injecting formic acid, which rapidly decomposes to $\mathrm{CO}_{2}$ and $\mathrm{H}_{2}$ at the conditions of the experiment (McCollom and Seewald, 2003). Isotopically labeled formic acid $\left(99 \% \mathrm{H}^{13} \mathrm{COOH}\right.$, Cambridge Isotope Labs) was used for this purpose to allow unequivocal identification of carbon sources and sinks during the experiment. Addition of unlabeled CO involved initially dissolving the gas in deionized water in a length of high pressure tubing before injection into the reaction cell. The activity of $\mathrm{H}^{+}$was varied by injecting either sodium bicarbonate $\left(\mathrm{NaHCO}_{3}\right)$ or sodium formate (NaHCOO) solutions. Isotopically labeled sodium bicarbonate was used for this purpose $(99 \%$ $\mathrm{NaH}^{13} \mathrm{CO}_{3}$, Cambridge Isotope Labs) after $1248 \mathrm{~h}$ to replenish the inventory of ${ }^{13} \mathrm{C}$ present in solution.

Throughout the course of the experiment, several fluid aliquots were removed from the reaction cell on a given sampling occasion into glass gas-tight syringes and analyzed for the concentration of dissolved species. Total dissolved $\mathrm{CO}_{2}\left(\Sigma \mathrm{CO}_{2}=\mathrm{CO}_{2}+\mathrm{HCO}_{3}{ }^{-}+\mathrm{CO}_{3}{ }^{\circ}\right)$ and $\mathrm{C}_{1}{ }^{-}$ $\mathrm{C}_{6}$ hydrocarbons were analyzed using a purge and trap apparatus interfaced directly to a gas chromatograph equipped with serially connected thermal conductivity and flame ionization detectors and a Porapak-Q packed column. Complete extraction of all carbonate species as $\mathrm{CO}_{2}$ was ensured by the presence of 25 wt. \% phosphoric acid in the purge cell. Dissolved $\mathrm{CO}$ and $\mathrm{H}_{2}$ were analyzed following a headspace extraction by gas chromatography using a thermal conductivity detector and $5 \AA$ molecular sieve packed column. Total dissolved formate $\left(\Sigma \mathrm{HCOOH}=\mathrm{HCOOH}+\mathrm{HCOO}^{-}\right)$and $\mathrm{Na}^{+}$were determined by ion chromatography with conductivity detection. Methanol and formaldehyde were determined by split injection of aqueous samples into a gas chromatograph equipped with an EC-WAX column and a flame ionization detector. Selected fluid samples were analyzed on a benchtop mass spectrometer (Hewlett Packard 5973 mass selective detector) to determine whether ${ }^{13} \mathrm{C}$ was being incorporated into methanol and $\mathrm{CH}_{4}$. Analytical uncertainties for all chemical species measured during this study are estimated at $\pm 5 \%(2 \sigma)$.

Concentrations of dissolved species in the reaction cell immediately after fluid addition were calculated from the amount and composition of fluids injected and known to exist in the 
reaction cell at the time of injection. Due to technical limitations associated with the addition of gaseous $\mathrm{CO}$, it was not possible to accurately determine the amount injected. Accordingly, the initial concentration of CO immediately after injection at $721.5 \mathrm{~h}$ is assumed to be equal to or greater than the concentration measured at $736.6 \mathrm{~h}$ (Table 1). This assumption has no impact on our interpretation of the experimental results since the calculated fluid composition at $721.5 \mathrm{~h}$ was not used for kinetic or thermodynamic assessments (see below).

The extent of chemical equilibrium during each stage of the experiment was evaluated by comparing measured concentrations of dissolved species with values predicted for equilibration of the reactions of interest. Requisite thermodynamic data for these calculations was generated from the SUPCRT92 database (Johnson et al, 1992) and additional data from Shock (1995). In situ $\mathrm{pH}$ values were calculated using computer program EQ3NR which takes into account the formation of aqueous complexes, activity coefficients of aqueous species, and carbon speciation (Wolery, 1992). In situ $\mathrm{pH}$ could not be calculated from measured $\mathrm{pH}\left(25^{\circ} \mathrm{C}\right)$ due to extensive exsolution of aqueous $\mathrm{CO}_{2}$ upon removal of fluid samples from the high pressure reaction cell into gas-tight syringes at ambient conditions.

\section{RESULTS}

\subsection{CO-CO $\mathrm{CO}_{2}$ Equilibration}

The initial phase of the experiment involved heating a $175 \mathrm{mmol} / \mathrm{kg}$ formic acid solution at $300^{\circ} \mathrm{C}$. Rapid decomposition of the formic acid resulted in almost complete conversion to equimolar concentrations of $\mathrm{H}_{2}$ and $\mathrm{CO}_{2}$ within the first $48 \mathrm{~h}$ of reaction, after which concentrations remained constant (Table 1, Fig. 3a). Production of aqueous CO was observed in the early stages of reaction, reaching concentrations of $0.83 \mathrm{mmol} / \mathrm{kg}$ in the first sample, and then remained constant with time. The concentration of $\Sigma \mathrm{HCOOH}$ decreased to $0.38 \mathrm{mmol} / \mathrm{kg}$ during the initial 48 hours of reaction and also remained constant with time. The measured steady state abundances of $\mathrm{H}_{2}, \Sigma \mathrm{CO}_{2}, \mathrm{CO}$, and $\Sigma \mathrm{HCOOH}$ are consistent with values predicted for thermodynamic equilibrium according to reactions (1) to (3) (Fig. 3a). At the relatively low in situ $\mathrm{pH}(\leq 3)$ of this experiment, $\mathrm{HCOOH}_{(\mathrm{aq})}$ and $\mathrm{CO}_{2(\mathrm{aq})}$ are the predominant species for 
$\Sigma \mathrm{HCOOH}$ and $\Sigma \mathrm{CO}_{2}$, respectively (Fig. 4). The similarity of observed and equilibrium fluid compositions in conjunction with steady state concentrations of $\mathrm{H}_{2}, \Sigma \mathrm{CO}_{2}, \mathrm{CO}$, and $\Sigma \mathrm{HCOOH}$, strongly suggests that the water-gas shift reaction had attained a state of thermodynamic equilibrium in less than $48 \mathrm{~h}$ at $300^{\circ} \mathrm{C}$.

A temperature reduction to $200^{\circ} \mathrm{C}$ at $266 \mathrm{~h}$ resulted in a substantial increase in the concentration of $\Sigma \mathrm{HCOOH}$ while the $\mathrm{CO}$ concentration decreased slightly (Fig. 3b). This variation is consistent with the minor temperature dependence of the equilibrium constant for reactions (2) and (3) (Fig. 2). Comparison of observed fluid composition with predicted values suggests that thermodynamic equilibrium was attained within $115 \mathrm{~h}$ of reaction at $200^{\circ} \mathrm{C}$ (Fig. 3b). Injection of deionized $\mathrm{H}_{2} \mathrm{O}$ at $385 \mathrm{~h}$ resulted in $\mathrm{CO}$ and $\Sigma \mathrm{HCOOH}$ concentrations that decreased to a greater extent than can be accounted for by simple dilution of the reaction cell contents and rapidly approached an equilibrium state within $118 \mathrm{~h}$ after $\mathrm{H}_{2} \mathrm{O}$ injection (Fig. 3c). In this case, equilibrium according to reaction (1) was approached from the direction of excess $\mathrm{CO}$, while during the first stage of the experiment at $300^{\circ} \mathrm{C}$, equilibrium was approached from the direction of insufficient CO. Taken together, these results demonstrate that the water-gas shift reaction attained reversible states of thermodynamic equilibrium on the time scale of a few days at 200 and $300^{\circ} \mathrm{C}$.

After $510 \mathrm{~h}$ of reaction, temperature was reduced to $150^{\circ} \mathrm{C}$. A small decrease in the abundance of $\mathrm{CO}$ and an increase in $\mathrm{\Sigma HCOOH}$ were observed in the first $71 \mathrm{~h}$ following the temperature change (Table 1), consistent with the thermodynamic predictions based on the temperature dependence for reactions (2) and (3). Injection of additional CO and water at $722 \mathrm{~h}$ yielded a dissolved CO concentration of approximately $172 \mathrm{mmol} / \mathrm{kg}$. Chemical interactions following injection resulted in continuous production of $\mathrm{H}_{2}, \Sigma \mathrm{CO}_{2}$, and $\Sigma \mathrm{HCOOH}$, and decreasing $\mathrm{CO}$ as the fluid composition moved toward, but did not achieve, an equilibrium state after $141 \mathrm{~h}$ (Fig. 3d). Rapid increases in reaction rates were observed after increasing temperature to $200^{\circ} \mathrm{C}$ (Fig. 3d). In particular, $\Sigma \mathrm{HCOOH}$ initially increased to a maximum concentration of $14 \mathrm{mmol} / \mathrm{kg}$ at $885 \mathrm{~h}$ before decreasing with continued reaction. The transient peak in $\mathrm{\Sigma HCOOH}$ abundance is consistent with the initial hydration of $\mathrm{CO}$ to form formic acid as an intermediate species (reaction 3 ) that is subsequently oxidized to $\mathrm{CO}_{2}$ (reaction 2). When 
measured after $312 \mathrm{~h}$ of reaction at $200^{\circ} \mathrm{C}$, the fluid had reached a composition consistent with thermodynamic equilibrium according to reactions (1) to (3) (Fig. 3d).

Injection of isotopically labeled sodium bicarbonate $\left(\mathrm{NaH}^{13} \mathrm{CO}_{3}\right)$ at $1248 \mathrm{~h}$ resulted in large decreases in the concentrations of $\mathrm{CO}, \mathrm{\Sigma CO}_{2}$, and $\mathrm{H}_{2}$, and production of $\mathrm{\Sigma HCOOH}$. Fluid speciation calculations conducted using the EQ3NR computer program yield an estimated in situ $\mathrm{pH}$ value of 8.2 at1674 h. Alkaline conditions favor the formation of formate $\left(\mathrm{HCOO}^{-}\right)$, bicarbonate $\left(\mathrm{HCO}_{3}{ }^{-}\right)$, and carbonate $\left(\mathrm{CO}_{3}{ }^{\circ}\right)$ according to the reactions:

$$
\begin{aligned}
& \mathrm{HCOOH}=\mathrm{H}^{+}+\mathrm{HCOO}^{-} \\
& \mathrm{CO}_{2(a q)}+\mathrm{H}_{2} \mathrm{O}=\mathrm{HCO}_{3}{ }^{-}+\mathrm{H}^{+} \\
& \mathrm{HCO}_{3}{ }^{-}=\mathrm{CO}_{3}{ }^{-}+\mathrm{H}^{+}
\end{aligned}
$$

which in turn decreases the equilibrium concentrations of $\mathrm{CO}, \mathrm{CO}_{2(\mathrm{aq})}$, and $\mathrm{HCOOH}$ (Fig. 4). Calculated activities of dissolved species in the $1674 \mathrm{~h}$ sample approached values consistent with an equilibrium state constrained by the measured $\mathrm{H}_{2}$ concentration (Fig. 3e). Similar calculations indicate an in situ $\mathrm{pH}$ of 8.8 after increasing temperature to $300^{\circ} \mathrm{C}$ at $1680 \mathrm{~h}$, and attainment of thermodynamic equilibrium appeared to occur within $188 \mathrm{~h}$ at this temperature. Dissolved $\mathrm{H}_{2}$ increased to $19 \mathrm{mmol} / \mathrm{kg}$ in the sample taken at $1867 \mathrm{~h}$ following the increase in temperature to $300^{\circ} \mathrm{C}$. The cause of this increase is unknown but may reflect oxidation of the titanium reaction cell closure piece in response to the increased temperature.

Injection of $\mathrm{NaHCOO}$ at $300^{\circ} \mathrm{C}$ after $1868 \mathrm{~h}$ of reaction produced substantial increases in $\mathrm{H}_{2}, \Sigma \mathrm{CO}_{2}, \mathrm{CO}$, and $\Sigma \mathrm{HCOOH}$ (Fig. 3f). Fluid speciation calculations indicate an in situ pH value of 8.7 and the abundances of dissolved carbon species reached levels consistent with thermodynamic equilibrium within a few hours after injection. Results of the experiment following injection of $\mathrm{NaH}^{13} \mathrm{CO}_{3}$ and $\mathrm{NaHCOO}$ demonstrate rapid attainment of reversible equilibrium according to reactions (1) to (3) and (5) to (7) at 200 to $300^{\circ} \mathrm{C}$.

\subsection{Methanol Formation}

Both formation and decomposition of methanol were observed during the course of the experiment. Mass spectrometric analyses prior to injection of unlabeled $\mathrm{CO}$ at $721.5 \mathrm{~h}$ indicates that within the resolution of the analysis, methanol produced during this phase of the experiment 
is composed entirely of labeled carbon (Fig. 5). Production of ${ }^{13} \mathrm{CH}_{3} \mathrm{OH}$ provides unequivocal evidence that this methanol was produced by the reduction of labeled carbon species and was not derived from decomposition of background carbon sources. In general, methanol concentrations remained constant at $150^{\circ} \mathrm{C}$ and for most of the $200^{\circ} \mathrm{C}$ phases of the experiment despite thermodynamic drives for production or destruction of this compound. At $300^{\circ} \mathrm{C}$, however, reactions rates were sufficiently rapid to cause methanol concentrations to increase when levels were below values required for thermodynamic equilibrium, and decrease when levels were in excess (Fig. 3a, 3d, 3e and 3f). The abundance of methanol approached near equilibrium values following injections of $\mathrm{NaH}^{13} \mathrm{CO}_{3}$ and $\mathrm{NaHCOO}$ at $300^{\circ} \mathrm{C}$ (Fig. 3e and 3f). A maximum methanol concentration of $2.0 \mathrm{mmol} / \mathrm{kg}$ was observed at $200^{\circ} \mathrm{C}$ in the $1200 \mathrm{~h}$ sample (Table 1), and likely reflects enhanced formation rates in response to the high concentrations of formic acid during this phase of the experiment.

Formaldehyde concentrations remained below the detection limit of our analytical technique $(0.01 \mathrm{mmol} / \mathrm{kg})$ in all fluids sampled during the experiment. Despite its lack of observation, formation of methanol from formic acid may have involved a formaldehyde intermediary (see Fig. 1) since its occurrence in solution at levels controlled by thermodynamic equilibrium would be well below our detection limit (Fig. 4).

\subsection{Methane Formation}

The formation of small amounts of $\mathrm{CH}_{4}$ (Table 1) along with lesser amounts of $\mathrm{C}_{2}-\mathrm{C}_{6}$ hydrocarbons (data not shown) was observed during the experiment. Mass spectrometric analysis of the sample at $48 \mathrm{~h}$ revealed that a small amounts of ${ }^{13} \mathrm{C}$ was incorporated in $\mathrm{CH}_{4}$, but not the longer chain hydrocarbons. The presence of ${ }^{12} \mathrm{C}$ in $\mathrm{CH}_{4}$ and $\mathrm{C}_{2+}$ hydrocarbons indicates pyrolysis of background carbon sources contributed some carbon species to solution during the experiment. Relatively low concentrations of $\mathrm{CH}_{4}$ relative to other carbon species indicates that the background sources of carbon were not large and did not contribute significantly to other single-carbon compounds observed in the experiment.

The presence of ${ }^{13} \mathrm{CH}_{4}$ at levels above natural abundances provides unequivocal evidence that some of the $\mathrm{CH}_{4}$ was derived by reduction of labeled carbon species. Reduction of $\mathrm{CO}_{2}$ to form $\mathrm{CH}_{4}$ can be represented by the overall reaction: 


$$
\mathrm{CO}_{2}+4 \mathrm{H}_{2}=\mathrm{CH}_{4}+\mathrm{H}_{2} \mathrm{O}
$$

During all phases of the experiment, thermodynamic constraints favor this reaction to proceed to the right. However, stable equilibrium was not attained due to slow reaction kinetics for the formation of $\mathrm{CH}_{4}$. This result is consistent with previous studies that have documented relatively sluggish reaction kinetics for the reduction of $\mathrm{CO}_{2}$ to $\mathrm{CH}_{4}$ under hydrothermal conditions in the absence of a catalyst (Berndt et al., 1996; Horita and Berndt, 1999; McCollom and Seewald, 2001, 2003, Foustoukos and Seyfried, 2004). Kinetic barriers that prevent the rapid formation of $\mathrm{CH}_{4}$ allowed $\Sigma \mathrm{CO}_{2}, \Sigma \mathrm{HCOOH}$, and $\mathrm{CO}$ to persist at relatively high concentrations during the experiments and attain metastable equilibrium states according to the reactions (1) to (3).

Temporal variations in the rate of $\mathrm{CH}_{4}$ production can be used to elucidate the reaction path responsible for reduction of aqueous $\mathrm{CO}_{2}$ to $\mathrm{CH}_{4}$. Although rapid $\mathrm{CH}_{4}$ production might be expected during the $300^{\circ} \mathrm{C}$ phases of the experiment due to the general positive correlation of increased reaction rates with the temperature, the fastest rate of $\mathrm{CH}_{4}$ production was actually observed at $200^{\circ} \mathrm{C}$ in the time period between increasing temperature at $863 \mathrm{~h}$ and the sample at $1175 \mathrm{~h}$ (Table 1). Although we did not determine the abundance of ${ }^{13} \mathrm{CH}_{4}$ during this phase of the experiment, the measured $\mathrm{CH}_{4}$ concentration at $1175 \mathrm{~h}$ was substantially higher than the amounts observed from background sources at the start of the experiment (Table 1), suggesting that it was derived from $\mathrm{CO}_{2}$ reduction. Methane production between 863 and $1175 \mathrm{~h}$ coincided with maximum methanol concentrations that approached $2 \mathrm{mmol} / \mathrm{kg}$. The close association of $\mathrm{CH}_{4}$ and methanol production suggests the latter species may represent a reaction intermediary during the formation of $\mathrm{CH}_{4}$ from $\mathrm{CO}_{2}$. Collectively, these data suggest that formation of $\mathrm{CH}_{4}$ from $\mathrm{CO}_{2}$ during the experiments may not involve a heterogeneously catalyzed Fischer-Tropschtype reaction, but instead may occurs via an homogenous, aqueous stepwise reduction path that produces $\mathrm{\Sigma HCOOH}$, possibly formaldehyde, and methanol as reaction intermediaries according to the sequence shown in Figure 1. 


\section{DISCUSSION}

\subsection{Retrieval of Kinetic Data}

Results of this study demonstrate that reactions involving $\Sigma \mathrm{CO}_{2}, \Sigma \mathrm{HCOOH}, \mathrm{CO}$, and methanol occur at measurable rates at 150 to $300^{\circ} \mathrm{C}$ on laboratory time scales and may attain metastable equilibrium states. During the experiment, the rate of $\mathrm{CO}$ disappearance is independent of thermodynamic drives when $\mathrm{CO}$ concentrations are far from equilibrium. A semi$\log$ plot of far from equilibrium $\mathrm{CO}$ concentrations as a function of time reveals linear relationships (Fig. 6), suggesting that rate of $\mathrm{CO}$ consumption is a first order process with respect to $\mathrm{CO}$ abundance. Because oxidation of $\mathrm{CO}$ to $\mathrm{CO}_{2}$ is a two-step process involving initial $\mathrm{CO}$ hydration (reaction 3) followed by oxidation of formic acid to $\mathrm{CO}_{2}$ (reaction 2), the rate of $\mathrm{CO}$ disappearance can only be used to estimate the overall rate of $\mathrm{CO}$ oxidation if formic acid oxidation is substantially faster than the initial hydration step. The relatively minor transient peak in the abundance of formic acid at $885.5 \mathrm{~h}$ indicates that this is the case during $\mathrm{CO}$ oxidation at $200^{\circ} \mathrm{C}$ (Table 1). Accordingly, the initial hydration of $\mathrm{CO}$ to formic acid appears to be the rate limiting step during $\mathrm{CO}$ oxidation, and the rate of the overall water-gas shift reaction can therefore be represented by the expression:

$$
\mathrm{d}[\mathrm{CO}] / \mathrm{d} t=k_{\mathrm{oxid}}[\mathrm{CO}]
$$

where $k_{\text {oxid }}$ is the rate constant for oxidation of $\mathrm{CO}$ to $\mathrm{CO}_{2},[\mathrm{CO}]$ is the concentration of aqueous $\mathrm{CO}$, and $t$ is time. Values of $k_{\text {oxid }}$ at 150 and $200^{\circ} \mathrm{C}$ were retrieved from fluid the composition of fluids sampled at 737 to $861 \mathrm{~h}$ and 863 to $918 \mathrm{~h}$, respectively. Linear regressions of $\log [\mathrm{CO}]$ plotted against time yield rate constants of $3.51 \times 10^{-7} \mathrm{~s}^{-1}$ and $7.67 \times 10^{-6} \mathrm{~s}^{-1}$ at 150 and $200^{\circ} \mathrm{C}$, respectively.

The temperature dependence of the rate constant can be described by the Arrhenius equation according to the relationship:

$$
\ln k_{\text {oxid }}=\ln A_{\mathrm{o}}-E_{a} / R T
$$

where $A_{\mathrm{o}}$ is the preexponential factor, $E_{a}$ is the activation energy, $R$ is the ideal gas constant, and $T$ is temperature in Kelvin. If it is assumed that reaction (3) is the rate limiting step during CO 
oxidation at temperatures $>>200^{\circ} \mathrm{C}$, then the results of our experiments can be compared with the data of Rice et al. (1998) who determined the rate of CO disappearance in supercritical water at 410,450 , and $480^{\circ} \mathrm{C}$ over a wide range of water densities. These investigators demonstrated that for a given temperature the natural $\log$ of $k_{\text {oxid }}$ varies linearly as a function of the natural $\log$ of water density. To assess the effect of temperature on the rate of $\mathrm{CO}$ oxidation at constant density, we extrapolated the rate data of Rice et al. (1998) to water densities during the experiments presented here. Ideally we would have also corrected the data from this study due to small differences in the density of water at 150 and $200^{\circ} \mathrm{C}$. This was not possible, however, because the dependence of $k_{\text {oxid }}$ on water density at 150 and $200^{\circ} \mathrm{C}$ is presently unknown. In the absence of such information, we opted to extrapolate the $k_{\text {oxid }}$ values retrieved by Rice et al. (1998) to the average of water densities for the $150^{\circ} \mathrm{C}\left(0.9354 \mathrm{~g} \mathrm{~cm}^{-3}\right)$ and $200^{\circ} \mathrm{C}\left(0.8879 \mathrm{~g} \mathrm{~cm}^{-3}\right)$ phases of the experiment at 350 bar.

Examination of Figure 7 reveals a linear temperature dependence for the value of $\ln k_{\text {oxid }}$ as a function of temperature from 150 to $480^{\circ} \mathrm{C}$ that is consistent with equation (10). A linear regression of the collective data yields a preexponential factor of $1.35 \times 10^{6} \mathrm{~s}^{-1}$ and an activation energy of $102 \mathrm{~kJ} \mathrm{~mol}^{-1}$. Some uncertainty is undoubtedly introduced to these values by our approximated water density for the 150 and $200^{\circ} \mathrm{C}$ rate data. Although the amount of this error cannot be determined directly, separate regression of the rate constants determined here at 150 and $200^{\circ} \mathrm{C}$ with Rice et al. (1998) values corrected for water densities at 150 and $200^{\circ} \mathrm{C}$, and 350 bar, indicates that values of $E_{a}$ are affected by less than $2 \mathrm{~kJ} \mathrm{~mol}^{-1}$, while values of $A_{\mathrm{o}}$ vary by less than an order of magnitude.

\subsection{Implications for Seafloor Hydrothermal Systems}

The abundance of $\mathrm{CO}, \Sigma \mathrm{HCOOH}$, formaldehyde, and methanol in seafloor hydrothermal systems will be regulated by the residence time of fluids in reaction zones and physical and chemical conditions in subsurface environments. A broad range of temperatures are associated with crustal circulation and seafloor venting of hydrothermal fluids. In ridge-crest systems, measured temperatures range from fluids marginally warmer than ambient $2^{\circ} \mathrm{C}$ seawater to temperatures approaching the critical point of seawater at $407^{\circ} \mathrm{C}$ (Von Damm, 1995). Variations observed for higher temperature fluids may reflect maximum subsurface conditions or varying 
degrees of cooling by subsurface mixing with cool seawater and/or conductive heat loss (Seewald and Seyfried, 1990; Seewald et al., 2003; Von Damm, 1995). In general, hydrothermal fluids in off-axis environments are characterized by lower temperatures. For example, the peridotite hosted Lost City vent field has a maximum measured temperature of $90^{\circ} \mathrm{C}$ (Kelley et al., 2001; 2005) while vents in the sediment covered flank of the Juan de Fuca Ridge have maximum recorded temperatures of $62^{\circ} \mathrm{C}$ (Wheat et al., 2000).

Kinetic data retrieved for the water-gas shift reaction during this study can be used to evaluate the likelihood that concentrations of $\Sigma \mathrm{CO}_{2}, \Sigma \mathrm{HCOOH}$, and $\mathrm{CO}$ will evolve towards and perhaps attain a state of thermodynamic equilibrium at prevailing temperature, $\mathrm{pH}$, redox conditions, and flow rates in subseafloor environments. At $350^{\circ} \mathrm{C}$, a typical temperature for black smoker vents, the calculated half-life for $\mathrm{CO}$ oxidation is on the order of 2 minutes, while at $100^{\circ} \mathrm{C}$, the reaction is characterized by a half-life of approximately 3 years (Figure 8). Residence times for ridge-crest hydrothermal fluids are poorly constrained, but estimates for high temperature fluids $\left(>200^{\circ} \mathrm{C}\right)$ at various vent fields along the Juan de Fuca Ridge are $\leq 3$ years (Kadko and Moore, 1988; Kadko and Butterfield, 1998). Minimum residence times at peak temperatures during circulation can be estimated from typical flow velocities and the depths to deep-seated reaction zones. If it is assumed that reaction zones are typically located at a depth of $1 \mathrm{~km}$ beneath the seafloor and fluid velocities of $2 \mathrm{~m} / \mathrm{sec}$ observed at the seafloor (Converse et al., 1984) extend to the reaction zone (i.e. pipe flow), then heated fluids must remain in the crust for a minimum of $500 \mathrm{sec}$. In real systems, however, pipe flow in subsurface environments does not occur and fluids must accelerate as they are focused in vent structures during ascent. Moreover, the above calculation does not account for time spent at elevated temperatures during recharge. Thus, it is likely that the residence time of high-temperature ridge-crest hydrothermal fluids is substantially longer than the half-life for reaction (1), which is less than 16 minutes at temperatures of $300^{\circ} \mathrm{C}$ and above. Considering the relative magnitudes of the residence times and the rates for $\mathrm{CO}$ oxidation, it is highly likely that $\Sigma \mathrm{CO}_{2}, \Sigma \mathrm{HCOOH}$, and $\mathrm{CO}$ will attain a state of thermodynamic equilibrium in high temperature seafloor hydrothermal fluids.

Testing the hypothesis that the water-gas shift reaction reaches thermodynamic equilibrium in high temperature ridge crest hydrothermal systems requires quantitative data for the concentrations of $\mathrm{CO}_{2}, \mathrm{CO}$, and $\mathrm{H}_{2}$ in vent fluids, as well as temperature and $\mathrm{pH}$. Presently, requisite data are only available from the Rainbow vent field, Mid-Atlantic Ridge (Charlou et al., 
2002) and the OBS and NGS vents at $21^{\circ}$ N, East Pacific Rise (Lilley et al., 1983; Welhan and Craig, 1983; Von Damm et al., 1985). Redox conditions in these fluids are markedly different and reflect the variable composition of the oceanic crust in subsurface reaction zones. The Rainbow hydrothermal system is a peridotite-hosted system characterized by aqueous $\mathrm{H}_{2}$ concentrations of $16 \mathrm{mmol} \mathrm{kg}^{-1}$ that result from serpentinization reactions (Berndt et al., 1996; McCollom and Seewald, 2001). In contrast, the $21^{\circ} \mathrm{N}$ system is hosted in basalt and $\mathrm{H}_{2}$ concentrations at the OBS and NGS vents are significantly lower at 1.5 and $0.65 \mathrm{mmol} \mathrm{kg}{ }^{-1}$, respectively. To evaluate the extent of thermodynamic equilibrium according to the water-gas shift reaction at Rainbow and $21^{\circ} \mathrm{N}$ EPR, chemical affinities $(A)$ were calculated according to the relationship:

$$
A=-R T \ln \left(Q / K_{e q}\right)
$$

where $R$ is the ideal gas constant, $T$ is temperature in Kelvin, $Q$ is the activity product, and $K_{e q}$ is the equilibrium constant. A positive chemical affinity indicates a thermodynamic drive for the reaction to proceed from left to right as written while a negative affinity indicates the opposite. Due to uncertainties in analytical and thermodynamic data, a value of zero is not expected for calculated affinities. For the purposes of this discussion, we consider calculated affinity values $<5 \mathrm{~kJ} /$ mole as being consistent with a state of thermodynamic equilibrium. Although this value is somewhat arbitrary, it is similar in magnitude to uncertainties typically reported in the literature for thermodynamic data. Despite the substantial differences in fluid composition, chemical affinities for reaction 1 vary from 0.1 to $4.9 \mathrm{~kJ} \mathrm{~mol}^{-1}$ (Table 2). These values, which are close to zero, indicate dissolved $\mathrm{CO}_{2}$ and $\mathrm{CO}$ concentrations in fluids at Rainbow and $21^{\circ} \mathrm{N}$ may have attained a state of thermodynamic equilibrium at the measured vent temperatures.

Rapid equilibration of the water-gas shift reaction during the experiments has substantial implications for understanding the potential for abiotic synthesis of organic compounds in hydrothermal systems. Theoretical models have shown that there is a strong thermodynamic drive for the formation of metastable aliphatic and aromatic hydrocarbons from $\mathrm{CO}_{2}$ as submarine hydrothermal solutions are cooled below approximately $300^{\circ} \mathrm{C}$ due to kinetic barriers that inhibit the formation of $\mathrm{CH}_{4}$ and graphite (Shock 1992, Zolotov and Shock, 1999). Zolotov and Shock (1999) point out that if kinetic barriers also prevent equilibration of $\mathrm{CO}$ with $\mathrm{CO}_{2}$ and 
$\mathrm{H}_{2}$ during cooling, quenching of elevated $\mathrm{CO}$ concentrations produced at high temperatures will result in a dramatic increase in the thermodynamic drive for abiotic organic synthesis from $\mathrm{CO}$ relative to synthesis from $\mathrm{CO}_{2}$. From a mechanistic perspective, enhanced $\mathrm{CO}$ concentrations may also facilitate Fischer-Tropsch-type reactions. Results of the experiments presented here in conjunction with observations from natural hydrothermal systems, however, suggest that reaction of $\mathrm{CO}$ with $\mathrm{CO}_{2}$ and $\mathrm{H}_{2}$ is a sufficiently rapid to maintain a state of thermodynamic equilibrium at temperatures typical of most submarine hydrothermal systems. Accordingly, unless cooling of submarine hydrothermal fluids is extremely rapid, $\mathrm{CO}$ concentrations will reflect equilibration with $\mathrm{CO}_{2}$ at the prevailing in situ fluid temperature and pressure, and thermodynamic drives for abiotic synthesis from $\mathrm{CO}$ and $\mathrm{CO}_{2}$ will be similar.

Because reaction between $\mathrm{CO}_{2}$ and $\mathrm{CO}$ in aqueous systems involves formation of a formic acid intermediate, equilibration of $\mathrm{CO}_{2}$ and $\mathrm{CO}$ in vent fluids from the Rainbow and $21^{\circ} \mathrm{N}$ hydrothermal fields implies that $\mathrm{LCOOH}$ should also be in equilibrium with these species. Compositional data do not exist for a similar assessment of the equilibrium state of methanol in hydrothermal fluids, but Vogelsonger et al. (2001) proposed that synthesis of methanol occurs in axial hot-springs during diking events based on laboratory experiments that demonstrated magnetite-catalyzed production of methanol in a gas phase. Our results show that methanol formation occurs readily in an aqueous phase at 200 to $300^{\circ} \mathrm{C}$ on laboratory time scales that are comparable to residence times for fluids in ridge-crest hydrothermal systems. Thus, methanol may be a ubiquitous component in $\mathrm{CO}_{2}$-bearing vent fluids, even in the absence of a gas phase and magnetite.

In order to evaluate the likely speciation of carbon in subseafloor hydrothermal systems, concentrations of single carbon species were predicted as a function of temperature and fluid composition (Fig. 9). For the purpose of these calculations, thermodynamic equilibrium between $\Sigma \mathrm{CO}_{2}, \mathrm{CO}$, methanol, $\Sigma \mathrm{HCOOH}$, and $\mathrm{H}_{2}$ was assumed, while $\mathrm{CH}_{4}$ was excluded from the equilibrium assemblage based on the experimental results and field observations that indicate kinetic barriers prevent its equilibration with other carbon species. Chemical conditions $\left(\Sigma \mathrm{CO}_{2}\right.$, $\mathrm{H}_{2}$, and $\mathrm{pH}$ ) were chosen to be representative of fluid compositions observed at many mid-ocean ridge vent systems (c.f. Von Damm, 1995).

Examination of Figure 9 reveals that lower temperatures and elevated $\mathrm{H}_{2}$ activities favor the formation of reduced carbon compounds. Under high $\mathrm{pH}$ conditions, $\mathrm{HCOO}^{-}$is stabilized 
while the concentrations of $\mathrm{CO}_{2}, \mathrm{CO}$, and methanol decrease. These trends suggest that large variations in the abundance of single carbon compounds can be expected for the broad range of geochemical environments that characterize subseafloor hydrothermal systems. For example, the high temperature peridotite-hosted hydrothermal system at Rainbow that vents relatively low $\mathrm{pH}$ fluids containing $16 \mathrm{mmolal}_{2}$ (Charlou et al., 2002), favors the formation of $\mathrm{CO}$, formic acid, and methanol-rich fluids (Fig. 9b). Relatively high CO concentrations would suggest that Fischer-Tropsch synthesis of hydrocarbons may be likely in this environment. In contrast, lowtemperature and high-pH at peridotite-hosted systems such as the Lost City hydrothermal field (Kelly et al., 2001, 2005) favor the formation of relatively minor CO (Fig. 9c). In reality, concentrations of aqueous carbon species at Lost City may be substantially lower than the values predicted in Figure 9c because calcite solubility at the high $\mathrm{pH}$ of Lost City fluids will limit $\Sigma \mathrm{CO}_{2}$ to very low abundances (Kelley et al., 2005). Accordingly, if $\mathrm{CO}$ represents a critical reactant for Fischer-Tropsch-type synthesis, then Lost City may not be the ideal environment for this type of reaction.

Relative to the more strongly reducing fluids like those at Rainbow and Lost City produced by reaction with peridotite, high temperature basalt-hosted systems characterized by lower $\mathrm{pH}$ and $\mathrm{H}_{2}$ concentrations are not expected to produce exceptionally high concentrations of $\Sigma \mathrm{HCOOH}$ and methanol, but should contain measurable CO (Fig. 9a). Significant amounts of reduced carbon compounds are expected, however, for conductively cooled high temperature basalt-hosted fluids (Fig. 9d) provided residence times are sufficiently long to accommodate reduced reaction rates at lower temperatures.

Cooling of high-temperature basalt-hosted fluids may also occur by mixing with cold seawater in subsurface environments. The effect of such mixing will be to enhance the relative stability of $\mathrm{\Sigma HCOOH}$ in response to lower temperatures and increased $\mathrm{pH}$, but increased aqueous concentrations may not be realized due to dilution of the $\Sigma \mathrm{CO}_{2}$-enriched hydrothermal fluid with relatively $\Sigma \mathrm{CO}_{2}$-poor seawater. To model the chemical evolution of hydrothermal fluids during mixing of high temperature basalt-hosted vent fluids with relatively cool seawater, we conducted a reaction path calculation using the EQ3NR/EQ6 computer code (Wolery, 1992; Wolery and Daveler, 1992) and a thermodynamic database generated at 250 bar from the SUPCRT92 database (Johnson et al., 1992). The model used is analogous to that described in McCollom and Shock (1997) in which mixing starts with $1 \mathrm{~kg}$ of $350^{\circ} \mathrm{C}$ hydrothermal fluid and incrementally 
adds $2^{\circ} \mathrm{C}$ seawater. After each increment is added, an equilibrium composition and speciation of the fluid is calculated at the new temperature by minimizing the Gibbs free energy of the entire system. Because the present and prior studies have demonstrated kinetic barriers that prevent equilibration of $\mathrm{CH}_{4}$ and more oxidized carbon species, reaction between $\mathrm{CH}_{4}$ and all other carbon species was suppressed during these calculations. Similarly, equilibration between $\mathrm{H}_{2} \mathrm{~S}$, $\mathrm{SO}_{4}$, and intermediate oxidation state sulfur species was suppressed because previous studies have shown sluggish reaction rates (Ohmoto and Lasaga, 1981). Although reaction rates between aqueous $\mathrm{H}_{2}$ in the hydrothermal fluid and $\mathrm{O}_{2}$ in seawater are unknown, we opted to suppress reaction between these two species so that we could isolate the effects of equilibration amongst carbon species on measured $\mathrm{H}_{2}$ concentrations. Retrieval of uncompromised $\mathrm{H}_{2}$ concentrations from hydrothermal fluid samples that have undergone significant mixing with $\mathrm{O}_{2}$-bearing seawater within fluid samplers (Seewald et al., 2002; 2003) suggests reaction between $\mathrm{H}_{2}$ and $\mathrm{O}_{2}$ may be sluggish. Quartz precipitation was suppressed in the model because quartz is rarely found in sulfide deposits formed by cooling of hydrothermal fluids and has been shown to behave conservatively during subsurface mixing (Von Damm and Lilley, 2004). The composition of Bio9 and Bio9' vents at 950'N EPR in November 1995 (Von Damm 2004; Von Damm and Lilley, 2004) was used as the representative high temperature fluid in the model (Table 3). This location was chosen because diffuse fluids at 9 50’ $\mathrm{N}$ EPR vent field are well-characterized and are in close proximity of focused flow high temperature vents (Von Damm, 2004; Von Damm and Lilley, 2004). Von Damm and Lilley (2004) have shown that diffuse fluids in this environment are produced by the subsurface mixing of seawater and nearby high temperature fluids.

Reaction path profiles for individual species indicate extensive reaction in response to changing temperature and chemical composition during mixing (Fig. 10). For example, $\mathrm{CH}_{3} \mathrm{OH}$ and $\mathrm{HCOO}^{-}$increase dramatically with continued mixing, reaching $\mu$ molal concentrations in the low temperature fluids (Fig. 10). Aqueous $\mathrm{HCOOH}$ also increases with mixing but subsequently decreases due to increased $\mathrm{pH}$ that favors the formation of $\mathrm{HCOO}^{-}$. The abundance of $\mathrm{H}_{2}$ is predicted to increase during the initial stages of mixing due to pyrite precipitation, but subsequently decreases as $\mathrm{CO}_{2}$ is reduced to form $\mathrm{CH}_{3} \mathrm{OH}, \mathrm{HCOO}^{-}$, and $\mathrm{HCOOH}$. Predicted decreases in the concentration of aqueous $\mathrm{CH}_{4}$ are limited to the effect of dilution by $\mathrm{CH}_{4}$-free seawater because reactions with other carbon species were suppressed in the model. Dissolved 
$\mathrm{CO}$ concentrations reach exceedingly low values in the low-temperature mixed fluid due to decreasing concentrations of $\mathrm{H}_{2}$ and $\mathrm{CO}_{2}$. These results demonstrate that mixing of a $\mathrm{CO}_{2}$-rich high temperature fluid with cool seawater may represent an effective mechanism to generate significant quantities of methanol and $\mathrm{\Sigma HCOOH}$ in low-temperature vent fluids. Because vent ecosystems are limited to the relatively low temperature regions of seafloor hydrothermal systems, abiotic production of reduced carbon species in situ may influence metabolic strategies. Filamentous chemolithotrophic bacteria living in hot-springs at Yellowstone National Park, United States, for example, have been shown to metabolize formate despite the presence of abundant $\Sigma \mathrm{CO}_{2}$ (Jahnke et al., 2001).

Comparisons of predicted fluid compositions for diffuse flow fluids at $9^{\circ} 50^{\prime} \mathrm{N}$ EPR reveal striking similarities. Indeed, a pervasive feature of the EPR fluids is aqueous $\mathrm{H}_{2}$ concentrations that are approximately an order of magnitude lower than would be expected for conservative dilution during mixing (Von Damm and Lilley, 2004), indicating the presence of subsurface redox-dependent reactions. Similar trends have been reported for diffuse fluids at Axial Volcano on the Juan de Fuca Ridge (Butterfield et al., 2004). The measured $\mathrm{H}_{2}$ concentration of $2.50 \mu$ molal in diffuse fluids collected in November 1995 in the vicinity of the Bio9 and Bio9' vents is reasonably consistent with the value of $3.96 \mu$ molal predicted by the model (Fig. 10). The ability of the theoretical model to reproduce the composition of natural fluids suggests reduction of $\mathrm{CO}_{2}$ to form methanol and $\Sigma \mathrm{HCOOH}$ may consume $\mathrm{H}_{2}$ during mixing at $9^{\circ} 50^{\prime} \mathrm{N}$ EPR. Presently data for the abundance of methanol and $\mathrm{\Sigma HCOOH}$ are not available to test this hypothesis. The possibility that abiotic equilibration of carbon species may deplete hydrothermal fluids in aqueous $\mathrm{H}_{2}$ concentrations has important implications for our understanding of microbial activity in a subsurface biosphere, since it removes $\mathrm{H}_{2}$ as an easily metabolized energy source. Von Damm and Lilley (2004) have suggested that the large $\mathrm{H}_{2}$ depletions at $9^{\circ} 50^{\prime} \mathrm{N}$ EPR are attributable to microbial utilization of $\mathrm{H}_{2}$ beneath the seafloor. The experimental and theoretical results presented here, however, suggest $\mathrm{H}_{2}$ consumption during mixing may not be a unique feature of microbial activity. 


\section{SUMMARY}

Hydrothermal experiments demonstrate that reversible reactions between $\Sigma \mathrm{CO}_{2}$, $\Sigma \mathrm{HCOOH}, \mathrm{CO}$, methanol, and $\mathrm{H}_{2}$ in aqueous systems can be readily observed on a laboratory time scale at temperatures $\geq 150^{\circ} \mathrm{C}$ without the addition of a heterogeneous catalyst. At temperatures $\geq 200^{\circ} \mathrm{C}$ aqueous single carbon compounds may attain a state of redox dependent metastable equilibrium that does not include $\mathrm{CH}_{4}$. Application of these results to submarine hydrothermal systems suggests that concentrations of single carbon compounds other than $\mathrm{CH}_{4}$ may reach equilibrium states and vary systematically as a function of total $\mathrm{C}$, the redox state of the fluid, and temperature. Thus, low-temperature basalt- and peridotite-hosted hydrothermal systems may generate reduced carbon compounds such as $\Sigma \mathrm{HCOOH}$ and methanol. Relatively low concentrations of $\mathrm{CO}$ predicted for low-temperature systems, however, suggest they may not be the optimum environment for abiotic synthesis of higher molecular weight reduced carbon compounds via Fischer-Tropsch-type processes. In contrast, peridotite-hosted systems characterized by high $\mathrm{H}_{2}$ abundance and temperatures near $350^{\circ} \mathrm{C}$ are expected to contain substantially higher $\mathrm{CO}$ concentrations that may enhance abiotic synthesis of longer chain hydrocarbons. The rather facile reaction between aqueous single carbon compounds at elevated temperatures suggests formation of reduced single carbon compounds is a natural consequence of the strong thermal and chemical gradients that characterize subseafloor hydrothermal systems on Earth and other planetary bodies. Such processes may play a critical role in the maintenance of microbial populations in present day vent ecosystems and the formation of organic precursors from which life evolved.

Acknowledgements - This study was supported by the National Science Foundation grant \#OCE-0136954, the Office of Basic Energy Sciences, U.S. Department of Energy grant \#DEFG0297ER14746, and by NASA Exobiology grant \#NAG5-7696 and Origins grant \#NNG04GG23G. Helpful reviews by Mike Mottl and an anonymous reviewer are appreciated. 


\section{REFERENCES}

Anderson R. B. (1984) The Fischer-Tropsch Reaction. London, Academic Press.

Bell J. L. S. and Palmer D. A. (1994) Experimental studies of organic acid decomposition. In: Organic Acids in Geological Processes (E .D. Pittman and M. D. Lewan, eds.), pp. 227-269. SpringerVerlag.

Bell J. S., Palmer D. A., Barnes H. L., and Drummond S. E. (1994) Thermal decomposition of acetate: III. Catalysis by mineral surfaces. Geochim. Cosmochim. Acta 58, 4155-4177.

Berndt M.E., Allen D.E., and Seyfried, W. E., Jr. (1996) Reduction of $\mathrm{CO}_{2}$ during serpentinization of olivine at $300^{\circ} \mathrm{C}$ and 350 bar. Geology 24, 351-354.

Burkhard D.J.M. and Ulmer G.C. (1995) Kinetics and equilibria of redox systems at temperatures as low as $300^{\circ}$ C. Geochim. Cosmochim. Acta 59, 1699-1715.

Butterfield D.A., K.K. Roe, M.D. Lilley, J.A. Huber, J.A. Baross, R.W. Embley, and G.J. Massoth (2004)

Mixing, reaction and microbial activity in the sub-seafloor revealed by temporal and spatial variation in diffuse flow vents at Axial Volcano, in The Subseafloor Biosphere at Mid-Ocean Ridges, AGU Monograph 144, W.S.D. Wilcock, E.F. DeLong, D.S. Kelley, J.A. Baross and S.C. Cary, eds., 269-289.

Charlou J.L., J.P. Donval, Y. Fouquet, P. Jean-Baptiste and N. Holm (2002) Geochemistry of high $\mathrm{H}_{2}$ and $\mathrm{CH}_{4}$ vent fluids issuing from ultramafic rocks at the Rainbow hydrothermal field $\left(36^{\circ} 14^{\prime} \mathrm{N}\right.$, MAR), Chemical Geology, 191(4), 345-359.

Converse D.R., H.D. Holland and J.M. Edmond (1984) Flow rates in the axial hot springs of the East Pacific Rise $\left(21^{\circ} \mathrm{N}\right)$ : Implications for the heat budget and the formation of massive sulfide deposits. Earth and Planetary Science Letters, 69(1), 159-175.

Craig, H., J.A. Welhan, K. Kim, R. Poreda and J.E. Lupton (1980) Geochemical studies of the $21^{\circ}$ N EPR hydrothermal fluids, EOS, 61(45), 992.

Deines P., Nafziger R.H., Ulmer G.C., and Woermann E. (1974) T- $f \mathrm{O}_{2}$ tables for selected gas mixtures in the C-H-O system. College Earth and Mineral Sci. Bull. Exp. Station 88. The Pennsylvania State Univ., University Park, PA.

Elliot, D.C., Sealock, L.J., Jr. (1983) Aqueous catalyst systems for the water-gas shift reaction. 1. Comparative catalyst studies. Ind. Eng. Chem. Prod. Res. Dev. 22, 426-431.

Foustoukos D.I. and W.E. Seyfried, Jr. (2004) Hydrocarbons in hydrothermal vent fluids: The role of chromium-bearing catalysts, Science, 304, 1002-1005. 
Horita J. and Berndt M. E. (1999) Abiogenic methane formation and isotopic fractionation under hydrothermal conditions. Science 285, 1055-1057.

Huebner J.S. (1987) Use of gas mixtures at low pressure to specify oxygen and other fugacities of furnace atmospheres. In Hydrothermal Experimental Techniques, (Ed. G. C. Ulmer and H. L. Barnes), pp. 20-60. John Wiley and Sons.

Jahnke L.L., W. Eder, R. Huber, J.M. Hope, K.-U. Hinrichs, J.M. Hayes, D.J. Des Marais, S.L. Cady, and R.E. Summons (2001) Signature lipids and stable carbon isotope analyses of Octopus Spring hyperthermophilic communities compared with those of Aquificales representatives. Appl Environ Microbiol., 67(11), 5179-5189.

Johnson J. W., Oelkers E. H., and Helgeson H. C. (1992) SUPCRT92: A software package for calculating the standard molal thermodynamic properties of minerals, gases, aqueous species, and reactions from 1 to 5000 bar and 0 to $1000^{\circ}$ C. Computers Geosci. 18, 899-947.

Kadko d. and Butterfield D. A. (1998) The relationship of hydrothermal fluid composition and crustal residence time to maturity of vent fluids on the Juan de Fuca Ridge. Geochim. Cosmochim. Acta 62, 1521-1533.

Kadko D. and Moore W. (1988) Radiochemical constraints on the crustal residence time of submarine hydrothermal fluids: Endeavour Ridge. Geochim. Cosmochim. Acta, 52(3), 659-668.

Kelley D. S., Karson J. A., Blackman D. K., et al. (2001) An off-axis hydrothermal vent field near the Mid-Atlantic Ridge at $30^{\circ}$ N. Nature 412, 145-149.

Kelley D. S., Karson J. A., Früh-Geen G.L., et al. (2005) A serpentine-hosted ecosystem: the Lost City hydrothermal field. Science 307, 1428-1434.

Lilley M.D., J.A. Baross, and Gordon L.I. (1983) Reduced gases and bacteria in hydrothermal fluids: The Galapagos spreading center and $21^{\circ} \mathrm{N}$ East Pacific Rise, in Hydrothermal Processes at Seafloor Spreading Centers, NATO Conf. Ser. IV (eds. P.E. Rona, K. Bostroem, L. Laubier and K.L. Smith, Jr) Plenum, New York, 411-449.

McCollom T. M. and Seewald J. S. (2001) A Reassessment of the Potential for Reduction of Dissolved $\mathrm{CO}_{2}$ to Hydrocarbons During Serpentinization of Olivine. Geochim. Cosmochim. Acta 65, 37693778.

McCollom T.M. and Seewald, J.S. (2003) Experimental constraints on the hydrothermal reactivity of organic acids and acid anions: I. formic acid and formate. Geochim. Cosmochim. Acta 67, $3625-$ 3644.

McCollom T.M. and Shock E.L. (1997) Geochemical constraints on chemolithoautotrophic metabolism by microorganisms in seafloor hydrothermal systems, Geochimica et Cosmochimica Acta, 61(20), 4375-4391. 
Melius C.F., N.E. Bergan, and Shepherd J.E. (1991) Effects of water on combustion kinetics at high pressure, Proceedings of the $23^{\text {rd }}$ Symposium (International) on Combustion, Amer. Chem. Soc, 217-223.

Ohmoto H. and Lasaga A.C. (1982) Kinetics of reactions between aqueous sulfates and sulfides in hydrothermal systems. Geochim. Cosmochim. Acta, 46(10), 1727-1745.

Nafziger R.H., Ulmer G.C., and Woermann E. (1971) Gaseous buffering for control of oxygen fugacity at one atmosphere. In Research Techniques for High Pressure and High Temperature (ed. G.C. Ulmer), pp. 9-41. Springer.

Rice S.F., Steeper R.R. and Aiken J.D. (1998) Water density effects on homogeneous water-gas shift reaction kinetics. J. Phys. Chem. A, 102(16), 2673 -2678.

Seewald J.S., Cruse A., and Saccocia P.J. (2003) Aqueous volatiles in hydrothermal fluids from the Main Endeavour Field, northern Juan de Fuca ridge: temporal variability following earthquake activity. Earth Planet. Sci. Lett. 216, 575-590.

Seewald J.S., Doherty K.W., Hammar T.R. and Liberatore S.P. (2002). A new gas-tight isobaric sampler for hydrothermal fluids, Deep-Sea Research 49, 189-196

Seewald J.S. and Seyfried W.E. Jr. (1990). The effect of temperature on heavy and base metal mobility in subseafloor hydrothermal systems: constraints from basalt alteration experiments and field studies. Earth Planet. Sci. Lett., 101, 388B403.

Seyfried W. E., Jr., Janecky D. R., and Berndt M. E. (1987) Rocking autoclaves for hydrothermal experiments, II. The flexible reaction-cell system. In Hydrothermal Experimental Techniques, (Ed. G. C. Ulmer and H. L. Barnes), pp. 216-239. John Wiley and Sons.

Shock E.L. (1992) Chemical environments of submarine hydrothermal systems; marine hydrothermal systems and the origin of life. Origins of Life and Evolution of the Biosphere, 22(1-4), 67-107.

Shock E.L. (1995) Organic acids in hydrothermal solutions: Standard molal thermodynamic properties of carboxylic acids and estimates of dissociation constants at high temperatures and pressures. Amer. J. Sci. 295, 496-580.

Ulmer G.C. (1984) $\mathrm{ZrO}_{2}$ oxygen and hydrogen sensors: a geologic perspective. In Adv. Ceramics 12, Science and Technology of Zirconica II, pp. 660-671. Amer. Ceram. Soc.

Voglesonger K.M., Holloway J.R., Dunn E.E., Dalla-Betta P.J., and O'Day P.A. (2001) Experimental abiotic synthesis of methanol in seafloor hydrothermal systems during diking events. Chem. Geol., 180(1-4), 129-139.

Von Damm K.L. (1995) Controls on the chemistry and temporal variability of seafloor hydrothermal fluids, in Seafloor Hydrothermal Systems: Physical, Chemical, Biological, and Geological 
Interactions, S. Humphris, R. Zierenberg, L. Mullineaux and R. Thomson (eds.), AGU Monograph, 91, 222-247.

Von Damm K.L. (2004) Evolution of the Hydrothermal System at East Pacific Rise 950’N: Geochemical Evidence for Changes in the Upper Oceanic Crust, in Mid-Ocean Ridges: Hydrothermal Interactions between the Lithosphere and Oceans, Geophysical Monograph Series 148, Christopher R. German, Jian Lin, and Lindsay M. Parson, eds. 285-304.

Von Damm K. L., Edmond J. M., Grant B., et al. (1985) Chemistry of submarine hydrothermal solutions at $21^{\circ} \mathrm{N}$, East Pacific Rise. Geochim. Cosmochim. Acta 49, 2197-2220.

Von Damm, K.L. and Lilley M.D. (2004) Diffuse flow hydrothermal fluids from 950'N East Pacific Rise: Origin, evolution and biogeochemical controls, in The Subseafloor Biosphere at Mid-Ocean Ridges, Geophyscial Monograph Series 144,W.S.D. Wilcock, E.F. DeLong, D.S. Kelley, J.A. Baross and S.C. Cary, eds, 245-268.

Welhan, J.A. and Craig H. (1983) Methane, hydrogen and helium in hydrothermal fluids at $21^{\circ} \mathrm{N}$ on the East Pacific Rise, in Hydrothermal Processes at Seafloor Spreading Centers, NATO Conf. Ser. IV (eds. P.E. Rona, K. Bostroem, L. Laubier and K.L. Smith, Jr) Plenum, New York, 391-409.

Wheat C.G., H. Elderfield, M.J. Mottl, Monnin C. (2000) Chemical composition of basement fluids within an oceanic ridge flank: Implications for along-strike and across-strike hydrothermal circulation, J. Geophys. Res., 105(B6), 13,437.

Wolery T. J. (1992) EQ3NR, A Computer Program for Geochemical Aqueous Speciation-Solubility Calculations: Theoretical Manual, User's Guide, and Related Documentation (Version 7.0), Lawrence Livermore Nat'l. Lab.

Wolery T.J. and Daveler S.A. (1992) EQ6, A Computer Program for Reaction Path Modeling of Aqueous Geochemical Systems: Theoretical Manual, User's Guide, and Related Documents. Lawrence Livermore National Lab.

Zolotov M. and Shock E. L. (1999) Abiotic synthesis of polycyclic aromatic hydrocarbons on Mars. J. Geophys. Res., 104(E6), 14,033-14049. 
Table 1. Concentrations of selected aqueous species during heating at 150 to $300^{\circ} \mathrm{C}$ and $350 \mathrm{bar}$.

\begin{tabular}{|c|c|c|c|c|c|c|c|c|}
\hline $\begin{array}{c}\text { Time } \\
\mathrm{h}\end{array}$ & $\begin{array}{c}\text { Temp } \\
{ }^{\circ} \mathrm{C}\end{array}$ & $\begin{array}{c}\mathrm{H}_{2} \\
\mathrm{mmol} / \mathrm{kg}\end{array}$ & $\begin{array}{c}\Sigma \mathrm{CO}_{2} \\
\mathrm{mmol} / \mathrm{kg}\end{array}$ & $\begin{array}{c}\mathrm{CO} \\
\mathrm{mmol} / \mathrm{kg}\end{array}$ & $\begin{array}{c}\mathrm{Na} \\
\mathrm{mmol} / \mathrm{kg}\end{array}$ & $\begin{array}{c}\mathrm{CH}_{4} \\
\mathrm{mmol} / \mathrm{kg}\end{array}$ & $\begin{array}{l}\mathrm{CH}_{3} \mathrm{OH} \\
\mathrm{mmol} / \mathrm{kg}\end{array}$ & $\begin{array}{r}\Sigma \mathrm{HCOOH} \\
\mathrm{mmol} / \mathrm{kg}\end{array}$ \\
\hline 0.0 & 300 & 0 & 0 & 0 & na & 0 & 0 & 175 \\
\hline 48.0 & 300 & 171 & 163 & 0.83 & na & 0.0060 & 0.37 & 0.38 \\
\hline 216.0 & 300 & 176 & 165 & 0.79 & na & 0.012 & 0.97 & 0.37 \\
\hline 266.0 & 200 & \multicolumn{7}{|c|}{ Temperature reduced to $200^{\circ} \mathrm{C}$} \\
\hline 290.0 & 200 & 167 & 164 & 0.73 & na & 0.016 & 1.1 & 3.1 \\
\hline 381.2 & 200 & na & na & na & na & na & 1.2 & 4.1 \\
\hline 385.0 & 200 & \multicolumn{7}{|c|}{ Added $28.8 \mathrm{~g} \mathrm{H}_{2} \mathrm{O}$ to $14.3 \mathrm{~g} \mathrm{H}_{2} \mathrm{O}$ in reaction cell } \\
\hline $385.0^{\dagger}$ & 200 & 55 & 54 & 0.24 & na & 0.0054 & 0.41 & 1.36 \\
\hline 409.3 & 200 & 59 & 56 & 0.097 & na & 0.0087 & 0.39 & 0.68 \\
\hline 502.8 & 200 & 59 & 54 & 0.078 & na & 0.0089 & 0.38 & 0.54 \\
\hline 509.8 & 150 & \multicolumn{7}{|c|}{ Temperature reduced to $150^{\circ} \mathrm{C}$} \\
\hline 551.5 & 150 & na & 50 & 0.066 & na & 0.0073 & 0.37 & 0.67 \\
\hline 572.7 & 150 & 57 & na & 0.071 & na & na & na & 0.73 \\
\hline 721.5 & 150 & \multicolumn{7}{|c|}{ Added $\mathrm{CO}$ and $29.7 \mathrm{~g} \mathrm{H}_{2} \mathrm{O}$ to $13.5 \mathrm{~g} \mathrm{H}_{2} \mathrm{O}$ in reaction cell } \\
\hline $721.5^{\dagger}$ & 150 & 18 & 16 & $\geq 172$ & na & 0.0023 & 0.12 & 0.23 \\
\hline 736.6 & 150 & na & 15 & 172 & na & 0.0044 & na & 0.98 \\
\hline 766.1 & 150 & 16 & 16 & 172 & na & 0.0045 & 0.10 & 1.1 \\
\hline 814.1 & 150 & 17 & 20 & 176 & na & 0.0044 & 0.10 & 3.3 \\
\hline 839.6 & 150 & 24 & na & 158 & na & na & na & 4.1 \\
\hline 861.0 & 150 & 25 & 22 & 143 & na & 0.0043 & 0.11 & 4.7 \\
\hline 862.8 & 200 & \multicolumn{7}{|c|}{ Increased temperature to $200^{\circ} \mathrm{C}$} \\
\hline 868.8 & 200 & 42 & 40 & 133 & na & 0.0045 & 0.10 & 8.6 \\
\hline 870.8 & 200 & 50 & na & 126 & na & na & na & 9.7 \\
\hline 885.5 & 200 & 89 & 82 & 86 & na & na & 0.11 & 14 \\
\hline 894.0 & 200 & na & na & 73 & na & na & na & na \\
\hline 918.0 & 200 & 146 & na & 31 & na & na & na & 12 \\
\hline 1174.5 & 200 & na & 173 & 1.0 & na & 0.14 & 1.7 & 4.4 \\
\hline 1200.3 & 200 & 166 & na & na & na & na & 2.0 & 4.5 \\
\hline 1247.8 & 199 & \multicolumn{7}{|c|}{ Added $34.6 \mathrm{~g}$ of $172 \mathrm{mmol} / \mathrm{kg} \mathrm{NaH}^{13} \mathrm{CO}_{3}$ to $2.6 \mathrm{~g} \mathrm{H}_{2} \mathrm{O}$ in reaction cell } \\
\hline $1247.8^{\dagger}$ & 199 & 12 & 172 & 0.072 & 160 & 0.010 & 0.15 & 0.32 \\
\hline 1314.8 & 199 & 6.5 & 152 & na & 162 & 0.011 & 0.16 & 3.1 \\
\hline 1509.7 & 199 & 2.4 & 152 & 0.00028 & 163 & 0.012 & 0.15 & 7.0 \\
\hline 1674.3 & 199 & 1.4 & 151 & 0.00040 & 160 & 0.011 & 0.16 & 7.7 \\
\hline 1679.7 & 300 & \multicolumn{7}{|c|}{ Increased temperature to $300^{\circ} \mathrm{C}$} \\
\hline 1867.2 & 300 & 19 & 138 & 0.0059 & 161 & 0.020 & 0.030 & 21 \\
\hline 1868.2 & 300 & \multicolumn{7}{|c|}{ Added $35.9 \mathrm{~g}$ of $195 \mathrm{mmol} / \mathrm{kg} \mathrm{NaHCOO}$ to $8.0 \mathrm{~g} \mathrm{H}_{2} \mathrm{O}$ in reaction cell } \\
\hline $1868.2^{\dagger}$ & 300 & 4.2 & 28 & 0.0011 & 189 & 0.0037 & 0.006 & 163 \\
\hline 1870.5 & 298 & 65 & 89 & 0.023 & 192 & 0.0044 & 0.002 & 93 \\
\hline 1872.6 & 299 & 77 & 103 & 0.021 & 192 & 0.0044 & 0.003 & 80 \\
\hline 2228.8 & 299 & 93 & 102 & 0.018 & 195 & 0.011 & 0.21 & 81 \\
\hline
\end{tabular}

${ }^{\dagger}$ Concentrations immediately after injection are calculated from the amount and composition of fluids injected and preexisting in the reaction cell at the time of injection.

na $=$ not analyzed 
Table 2. Fluid chemistry and chemical affinities $(A)$ for the water-gas shift reaction at Rainbow vent field, Mid-Atlantic Ridge and OBS and NGS vents, $21^{\circ} \mathrm{N}$ East Pacific Rise.

\begin{tabular}{lccc}
\hline Location & Rainbow $^{\dagger}$ & OBS $^{\ddagger}$ & NGS $^{\ddagger}$ \\
\hline $\mathrm{T}\left({ }^{\circ} \mathrm{C}\right)$ & 365 & 350 & 350 \\
Depth $(\mathrm{m})$ & 2300 & 2500 & 2500 \\
$\mathrm{CO}_{2}(\mathrm{mmol} / \mathrm{kg})$ & 16 & 5.7 & 5.7 \\
$\mathrm{CO}(\mathrm{nmol} / \mathrm{kg})$ & 5000 & 311 & 110 \\
$\mathrm{H}_{2}(\mathrm{mmol} / \mathrm{kg})$ & 16 & 1.5 & 0.65 \\
$\mathrm{CH}_{4}(\mathrm{mmol} / \mathrm{kg})$ & 2.5 & 0.06 & 0.07 \\
$\mathrm{CO}_{2(a q)}+\mathrm{H}_{2(a q)}=\mathrm{CO}_{(a q)}+\mathrm{H}_{2} \mathrm{O}_{(l)}$ & & \\
\hline$A_{250 \text { bar }}\left(\mathrm{kJ} \mathrm{mol}^{-1}\right)$ & 4.9 & 1.0 & 2.1 \\
$A_{500 \text { bar }}\left(\mathrm{kJ} \mathrm{mol}^{-1}\right)$ & 3.9 & 0.5 & 1.5 \\
$A_{1000 \text { bar }}\left(\mathrm{kJ} \mathrm{mol}^{-1}\right)$ & 3.4 & 0.1 & 1.2
\end{tabular}

${ }^{\dagger}$ Compositional data from Charlou et al. (2002)

* Compositional data from Lilley et al. (1983), Welhan \& Craig (1983).

Craig et al. (1980) 
Table 3. Starting fluid compositions ( $\mathrm{mmol} / \mathrm{kg}$ ) used for seawater-hydrothermal fluid mixing calculations.

\begin{tabular}{lcc}
\hline Species & Seawater & Hydrothermal Fluid \\
\hline $\mathrm{Na}^{+}$ & 468 & 391 \\
$\mathrm{~K}^{+}$ & 10.2 & 14.5 \\
$\mathrm{Ca}^{2+}$ & 10.3 & 24 \\
$\mathrm{Mg}^{2+}$ & 52.3 & 0 \\
$\mathrm{Fe}^{2+}$ & 0 & 6.03 \\
$\mathrm{Cl}^{-}$ & 544 & 466 \\
$\mathrm{SO}_{4}{ }^{2-}$ & 28.3 & 0 \\
$\mathrm{SiO}_{2(a q)}$ & 0.155 & 14.8 \\
$\Sigma \mathrm{H}_{2} \mathrm{~S}$ & 0 & 5.28 \\
$\Sigma \mathrm{CO}_{2}$ & 2.02 & 139 \\
$\mathrm{CH}_{4}$ & 0 & 0.084 \\
$\mathrm{H}_{2}$ & 0 & 0.36 \\
$\mathrm{pH}_{\text {(in situ }}$ & 8.2 & 4.5 \\
${ }^{\dagger}$ Hydrothermal fluid composition is from the Bio9 and Bio9' \\
vents at 9 950', East Pacific Rise in November, 1995 \\
(Von Damm and Lilley, 2004; Von Damm 2004)
\end{tabular}




\section{FIGURE CAPTIONS}

Figure 1. Schematic representation of redox reactions that may regulate the speciation of single carbon compounds under hydrothermal conditions.

Figure 2. Temperature dependence of the equilibrium constant $\left(K_{e q}\right)$ at 350 bar for selected aqueous reactions involving single carbon compounds. Requisite thermodynamic data for the construction of this figure are from the compilation of Johnson et al. (1992) and Shock (1995).

Figure 3. Variations in the concentrations of dissolved species during reaction of aqueous solutions at a) $300^{\circ} \mathrm{C}$ following addition of $\mathrm{H}^{13} \mathrm{COOH}$, b) $200^{\circ} \mathrm{C}$ following reduction in temperature from $300^{\circ} \mathrm{C}$, c) $200^{\circ} \mathrm{C}$ following dilution with deionized $\mathrm{H}_{2} \mathrm{O}$, d) 150 and $200^{\circ} \mathrm{C}$ following addition $\mathrm{CO}$, e) 200 and $300^{\circ} \mathrm{C}$ following addition of $\mathrm{NaH}^{13} \mathrm{CO}_{3}$, and f) $300^{\circ} \mathrm{C}$ following addition of $\mathrm{NaHCOO}$. The dashed horizontal lines represent predicted concentrations of the indicated species at thermodynamic equilibrium assuming kinetic barriers prevent significant quantities of $\mathrm{CH}_{4}$ and $\mathrm{CH}_{3} \mathrm{OH}$ from forming. In figures e) and $\mathrm{f}$ ) the equilibrium abundances were calculated for the measured aqueous $\mathrm{H}_{2}$ concentrations in the final sample at each temperature condition. The dashed-dot lines indicate the concentration of $\mathrm{CH}_{3} \mathrm{OH}$ required for thermodynamic equilibrium with the measured concentrations of $\Sigma \mathrm{CO}_{2}$ and $\mathrm{H}_{2}$ in the final sample of each stage of the experiment.

Figure 4. Variation in the abundance of aqueous species as a function of $\mathrm{pH}$ at $300^{\circ} \mathrm{C}$ and 350 bar in a solution initially containing 175 mmolal total $\mathrm{C}$ and $\mathrm{H}_{2}$. Dissolved $\mathrm{CH}_{4}$ was not considered in the chemical model due to kinetic barriers that prevent its formation on the time scale of laboratory experiments. Activity coefficients for all aqueous species were assumed to be unity. Requisite thermodynamic data for the construction of this figure are from the compilation of Johnson et al. (1992) and Shock (1995).

Figure 5. Mass spectrum of a) ${ }^{13} \mathrm{C}$-labeled methanol in the $503 \mathrm{~h}$ fluid sample from the experiment and b) a methanol standard containing natural abundances of carbon isotopes. 
Production of completely ${ }^{13}$-labeled methanol at $503 \mathrm{~h}$ indicates formation via the reduction of labeled carbon species.

Figure 6. Semi-log plot of far from equilibrium $\mathrm{CO}$ concentrations as a function of time during reaction of aqueous solutions at 150 and $200^{\circ} \mathrm{C}$. The linear relationships indicate that the decomposition of $\mathrm{CO}$ can be described by a first order rate expression with respect to $\mathrm{CO}$ concentration.

Figure 7. Arrhenius plot of rate constants retrieved from the experimental data presented in this study and rate constants in supercritical water from Rice et al. (1998) for the water-gas shift reaction. A linear regression of the data yields an activation energy $\left(E_{a}\right)$ of $102 \mathrm{~kJ} / \mathrm{mole}$ and a preexponential factor $\left(A_{0}\right)$ of $1.35 \times 10^{6}$.

Figure 8. Calculated half-life (sec) for the oxidation of $\mathrm{CO}$ to $\mathrm{CO}_{2}$ according to the water-gas shift reaction (reaction 1).

Figure 9. Predicted concentrations of selected carbon species as a function of $\mathrm{pH}$, a) and c), and $\mathrm{H}_{2}$ concentration b) and d). A total carbon concentration of 10 mmolal was used in all plots. Dissolved $\mathrm{CH}_{4}$ was not considered in the chemical model. Activity coefficients for all aqueous species were assumed to be unity. Requisite data for the construction of this figure are from the thermodynamic compilation of Johnson et al. (1992) and Shock (1995).

Figure 10.Variations in the concentration of selected aqueous carbon species and $\mathrm{H}_{2}$ predicted by a theoretical reaction path model during mixing of a $350^{\circ} \mathrm{C}$ black-smoker hydrothermal fluid and $2^{\circ} \mathrm{C}$ seawater (see text). The results are plotted against $\mathrm{SiO}_{2}$ because it is a conservative tracer of mixing in hydrothermal fluids. The initial fluid compositions used for the model are shown in Table 3. The open circles represent observed concentrations of the indicated species in diffuse fluids from 9 ${ }^{\circ} 50^{\prime} \mathrm{N}$ EPR (Von Damm and Lilley, 2004). The solid circle represents the predicted concentration of $\mathrm{H}_{2}$ in diffuse fluids $9^{\circ} 50^{\prime} \mathrm{N}$ EPR in the hypothetical case of conservative behavior during mixing. 


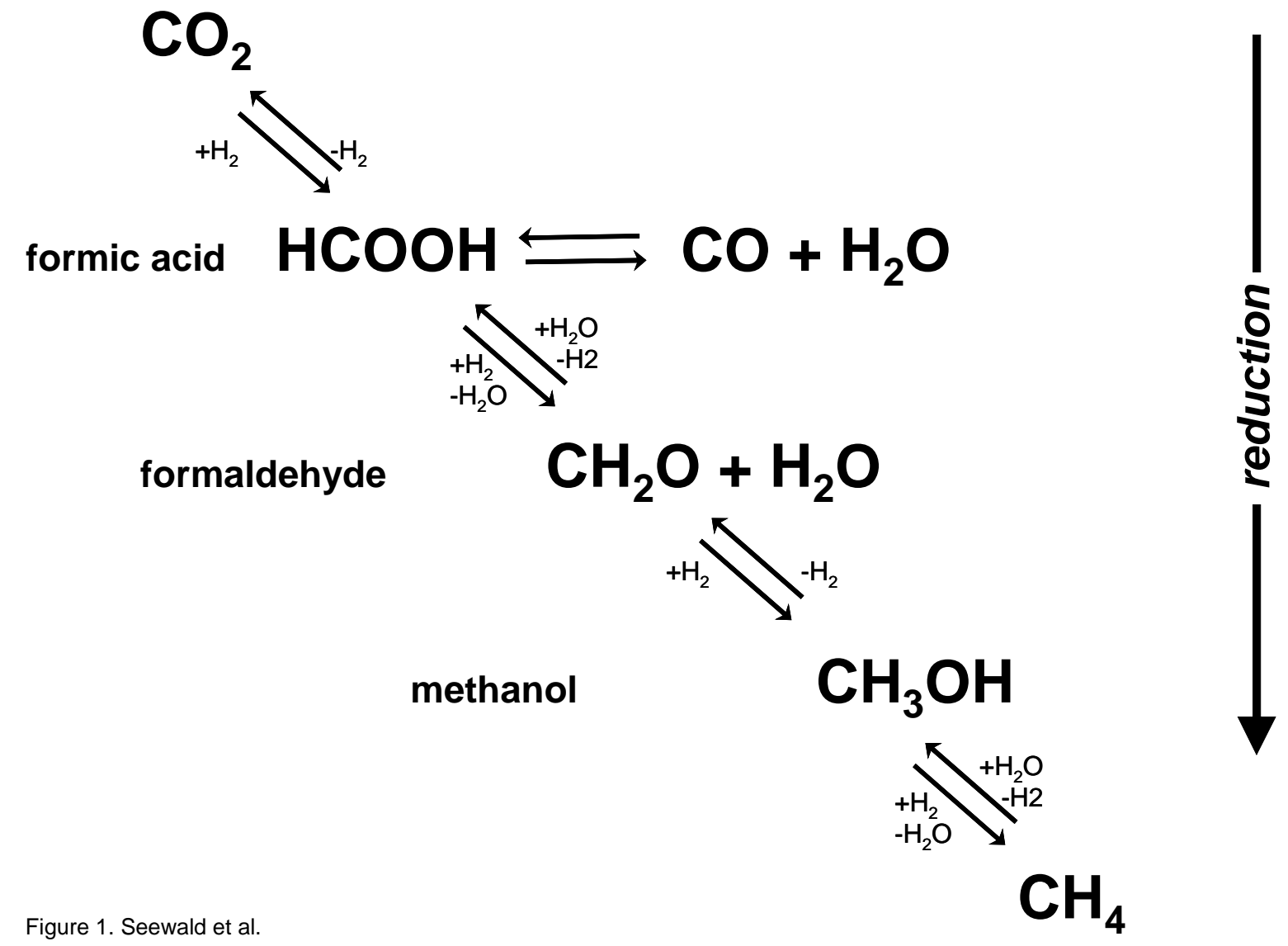




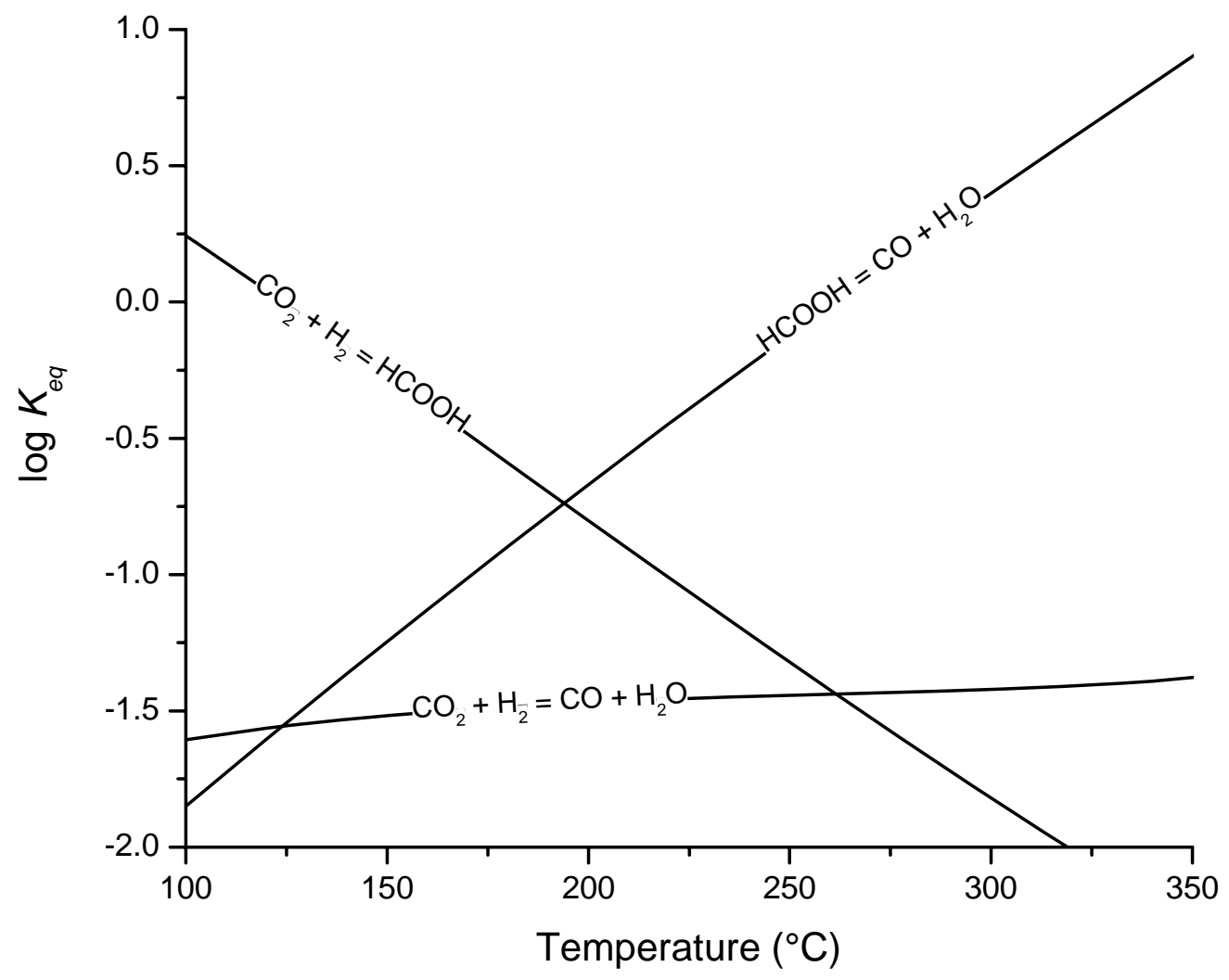

Figure 2. Seewald et al. 

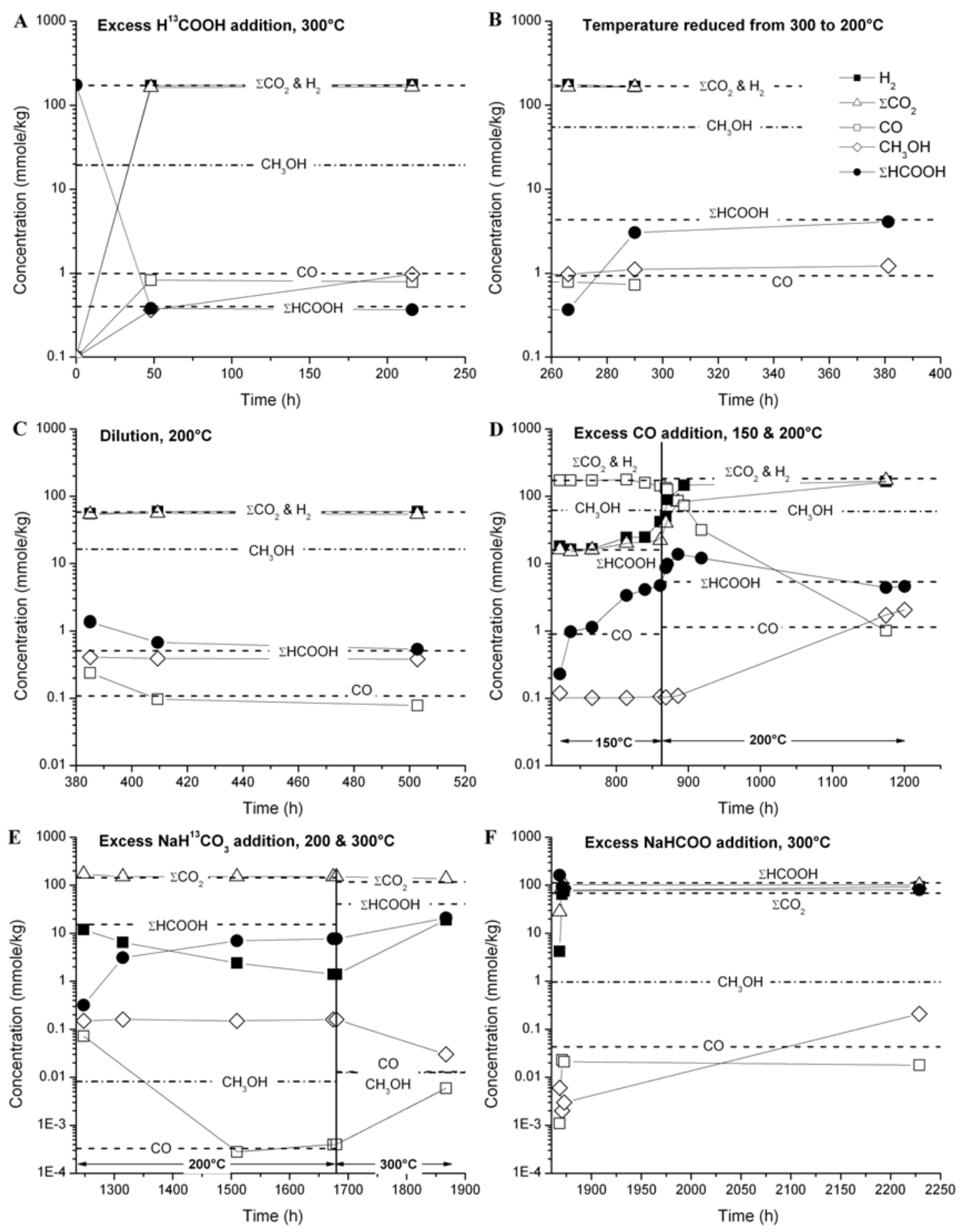

Figure 3. Seewald et al. 


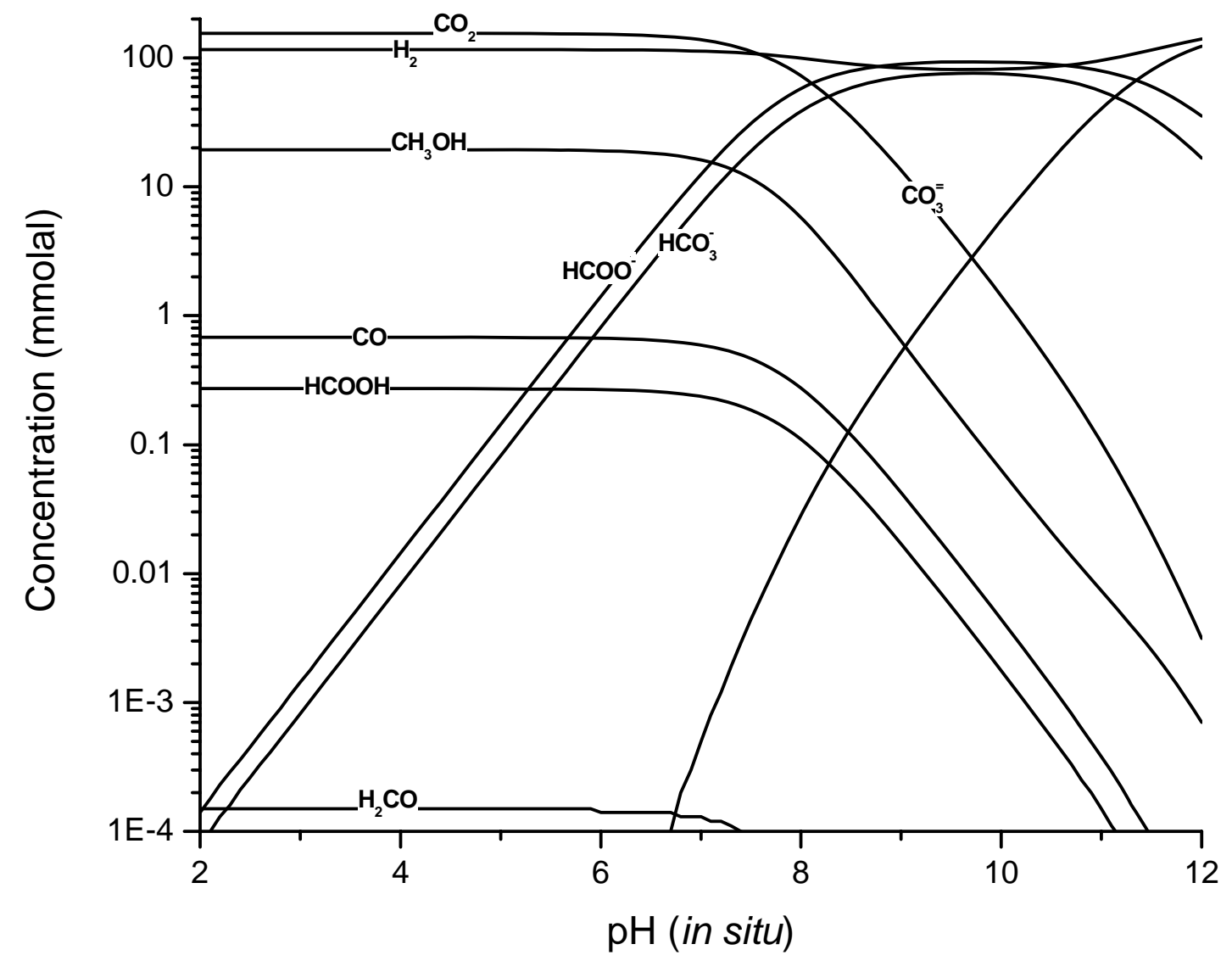

Figure 4. Seewald et al. 

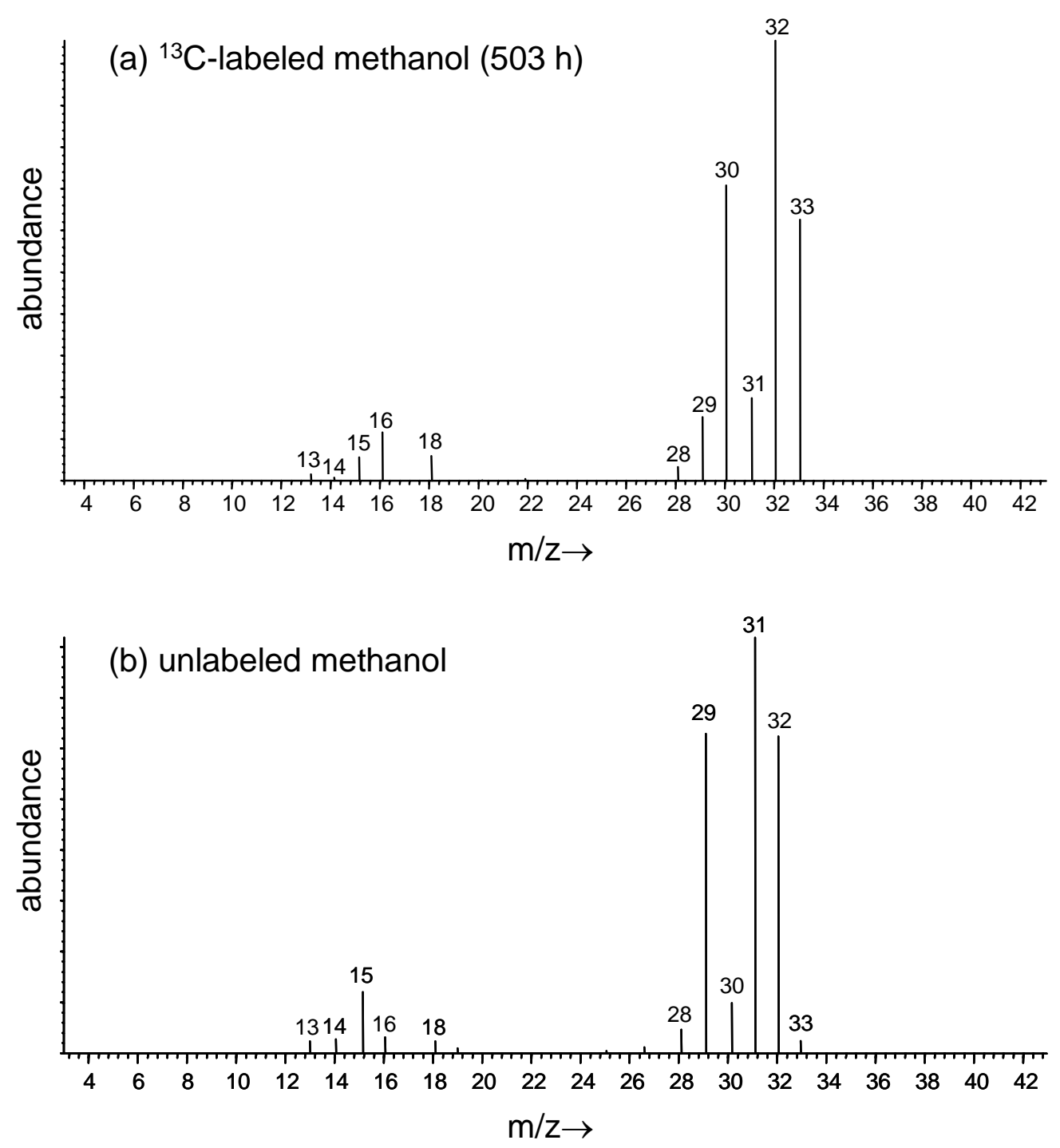

Figure 5. Seewald et al. 


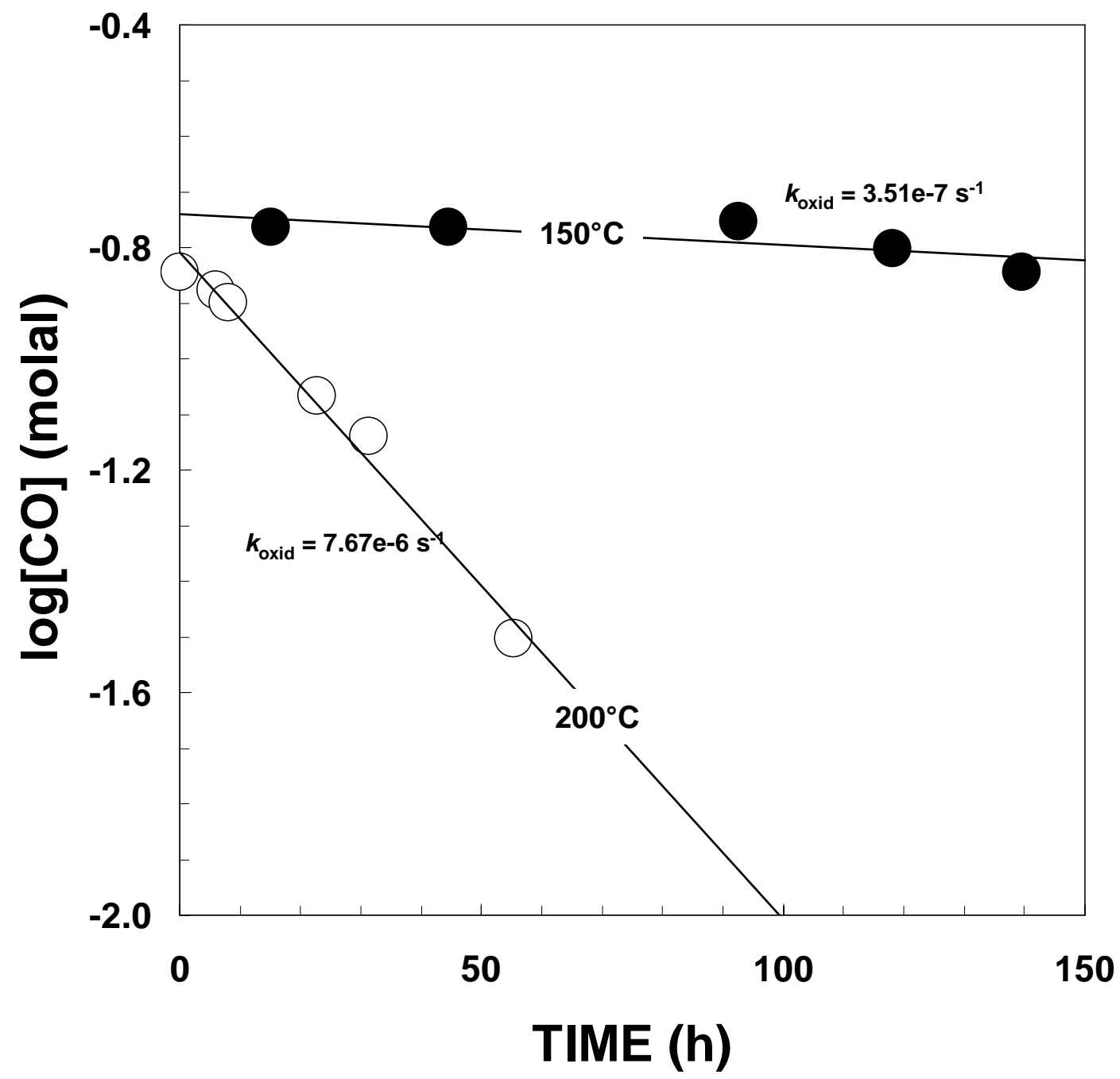

Figure 6. Seewald et al. 


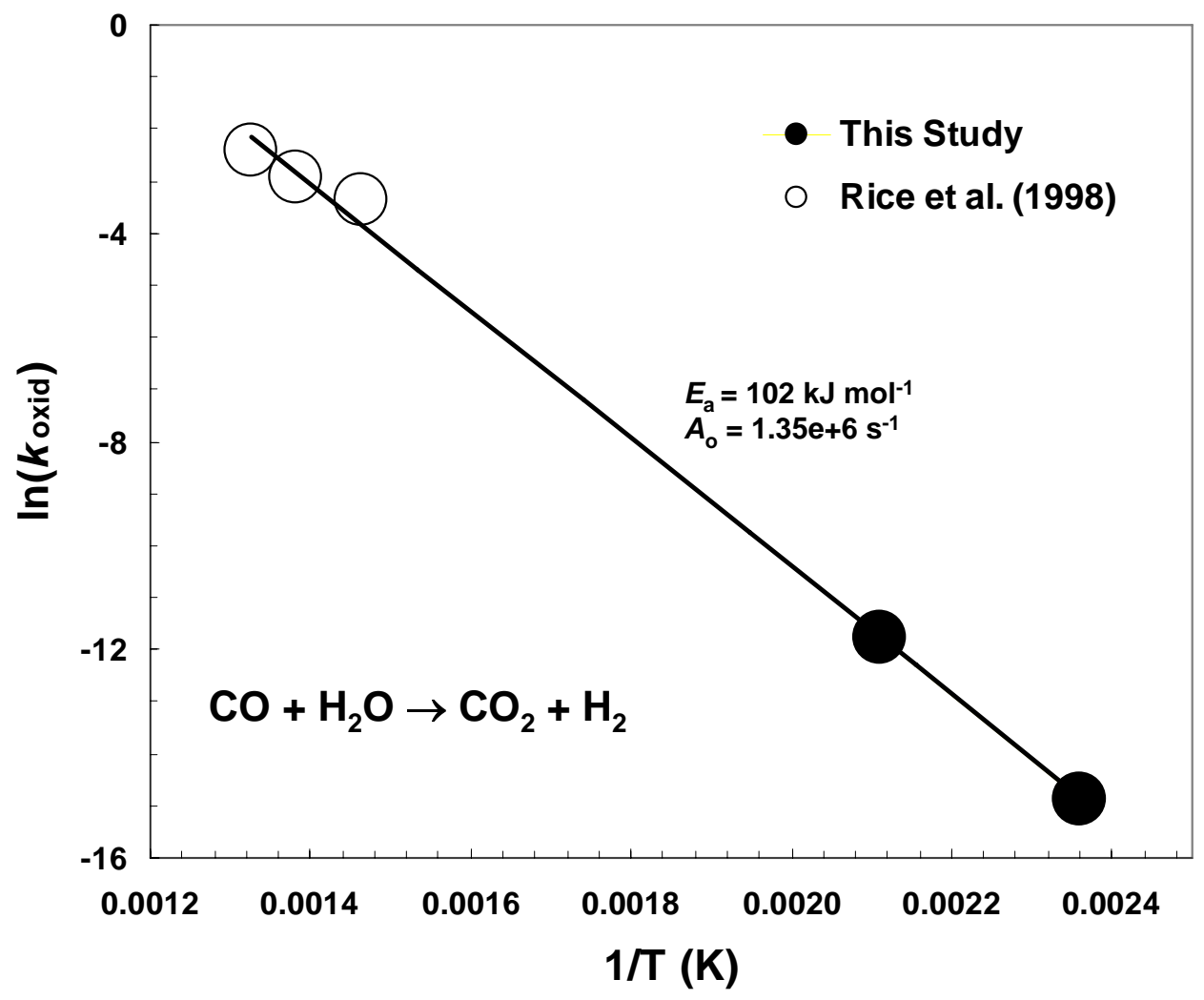

Figure 7. Seewald et al. 


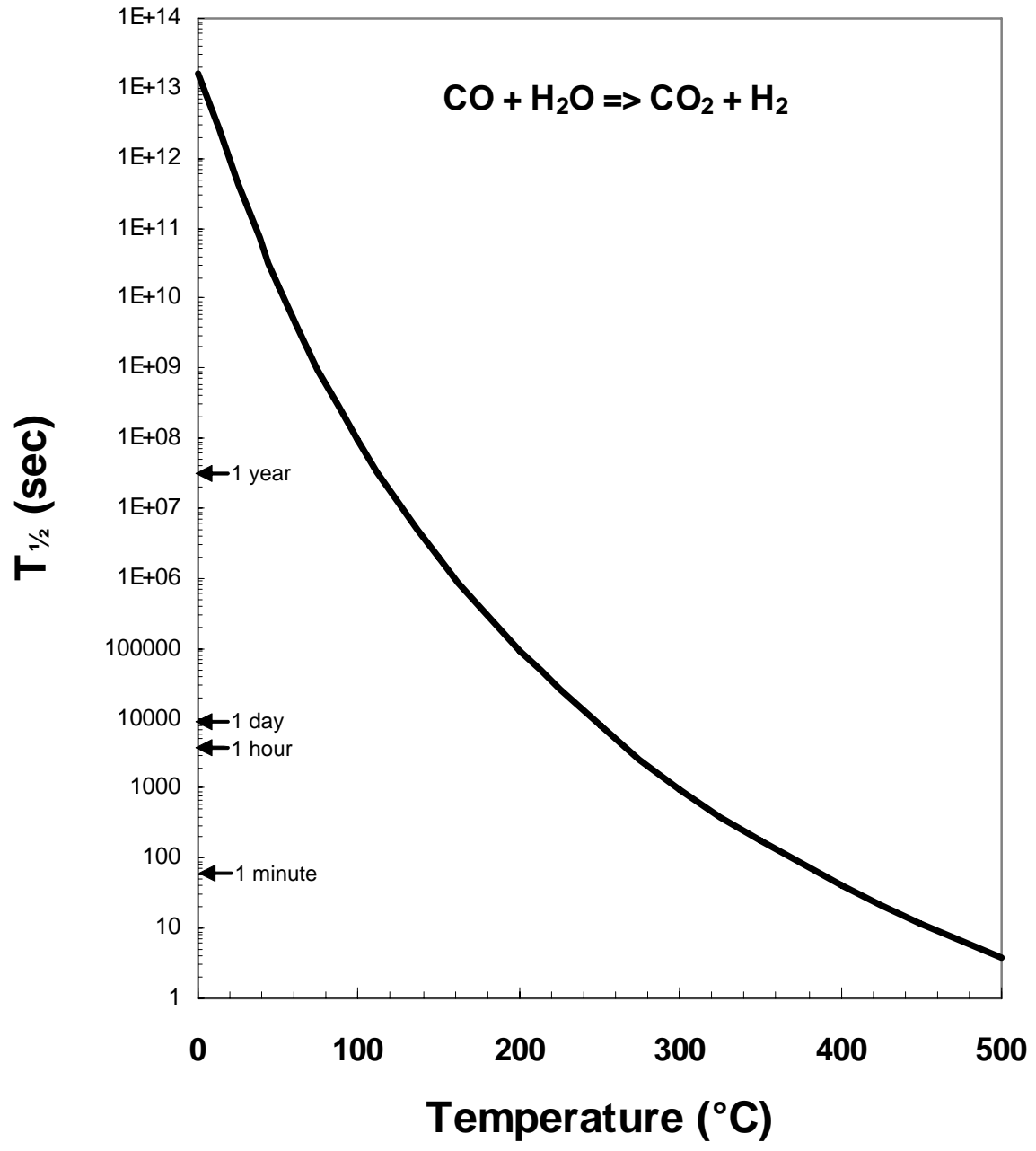

Figure 8. Seewald et al. 

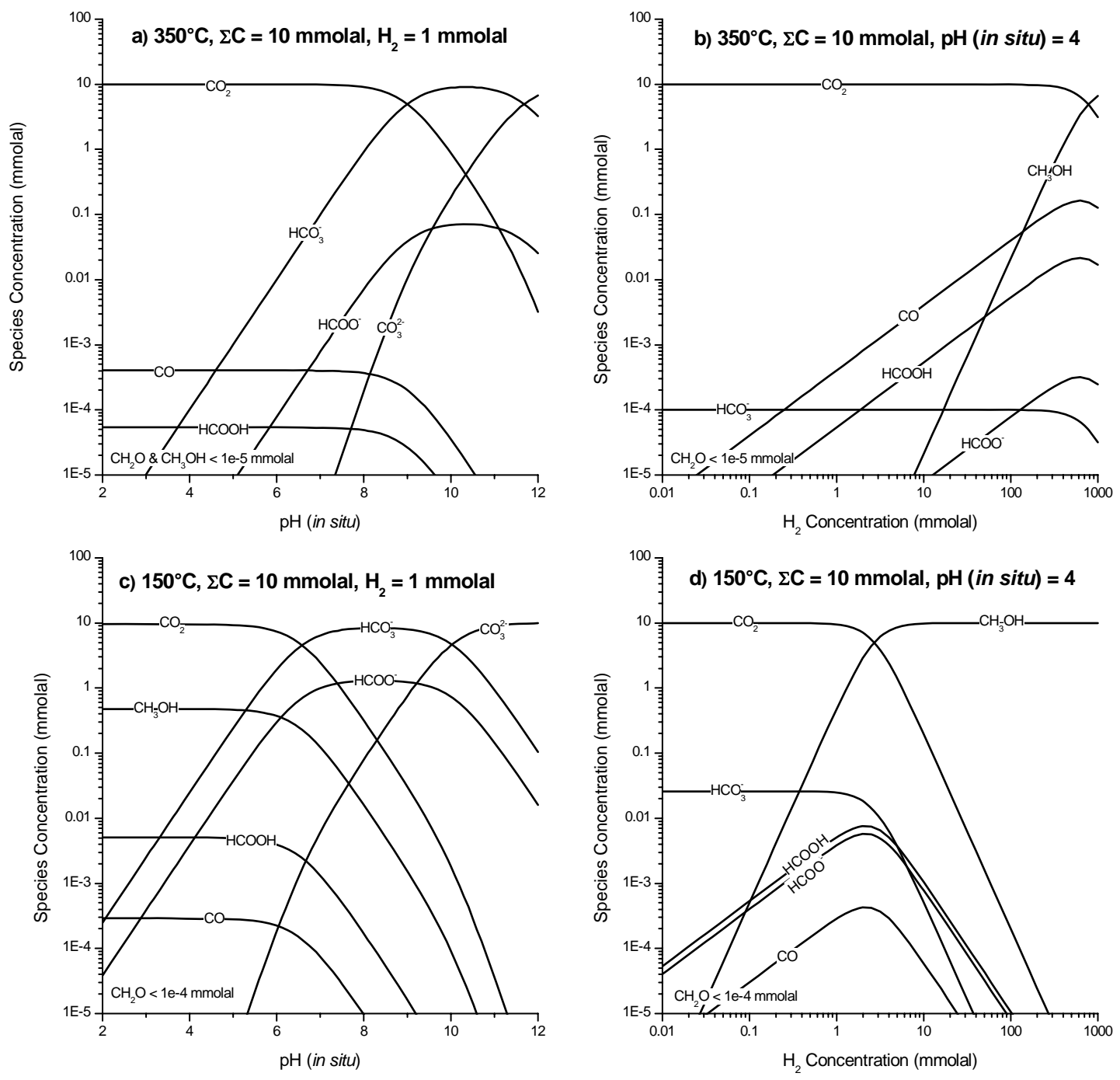

Figure 9. Seewald et al. 


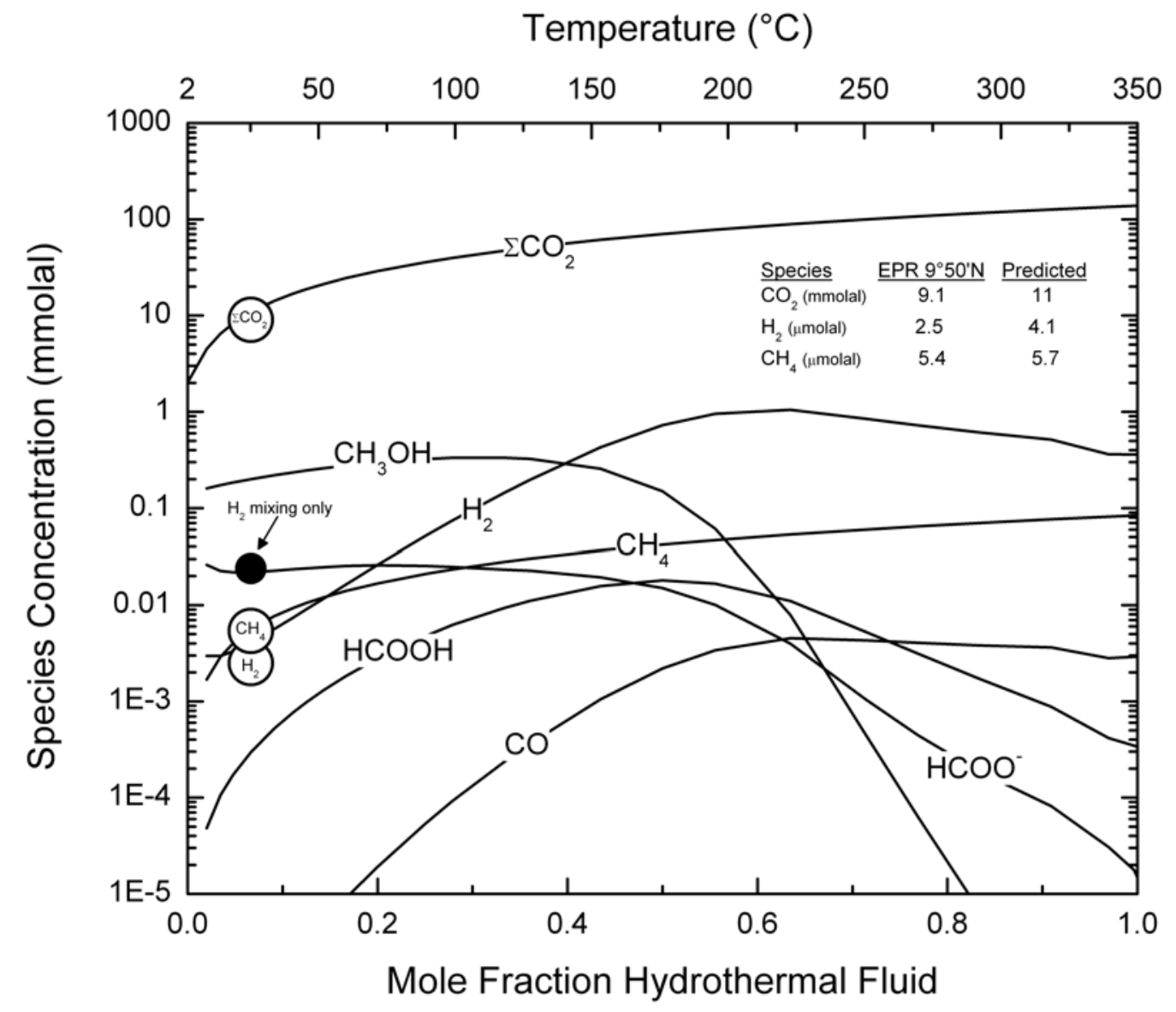

Figure 10. Seewald et al. 